\title{
Volatile Organic Compound Emissions from Surface Coating Facilities: Characterization of Facilities, Estimation of Emission Rates, and Dispersion Modeling of Off-Site Impacts
}

\author{
Annabrabha Athappan ${ }^{1}$, Sulak Sumitsawan ${ }^{2}$, Roja Haritha Gangupomu ${ }^{1}$, Ketwalee Kositkanawuth ${ }^{1}$, \\ Parthen Parikh', Benjamin Afotey ${ }^{3}$, Neelesh Sule ${ }^{4}$, Sahithi Raj Kalidindi', Melanie L. Sattler ${ }^{1}$, \\ Yvette Pearson Weatherton ${ }^{1}$
}

${ }^{1}$ Department of Civil Engineering, The University of Texas at Arlington, Arlington, USA; ${ }^{2}$ School of Energy and Environment, University of Phayao, Phayao, Thailand; ${ }^{3}$ Department of Chemical Engineering, Kwame Nkrumah University of Science and Technology, Kumasi, Ghana; ${ }^{4}$ Providence Engineering, Irving, USA.

Email: sattler@uta.edu

Received May 26 ${ }^{\text {th }}, 2013$; revised June 29 ${ }^{\text {th }}, 2013$; accepted August $3^{\text {rd }}, 2013$

Copyright (c) 2013 Annabrabha Athappan et al. This is an open access article distributed under the Creative Commons Attribution License, which permits unrestricted use, distribution, and reproduction in any medium, provided the original work is properly cited.

\begin{abstract}
Surface coating facilities are major sources of volatile organic compounds (VOCs) in urban areas. These VOCs can contribute to ground-level ozone formation, and many are hazardous air pollutants (HAPs), including xylene, ethylbenzene, and toluene. This project was conducted in order to provide information for updating the Texas Commission on Environmental Quality (TCEQ), USA, permit by rule for Surface Coating Facilities. Project objectives were: 1) To develop a database of information regarding surface coating facilities in Texas; 2) To estimate maximum emission rates for various VOC species from surface coating facilities in Texas; 3) To conduct dispersion modeling to estimate off-site impacts from surface coating facilities. The database was developed using 286 TCEQ permit files authorizing surface coating facilities in Texas during 2006 and 2007. The database was designed to include information important for estimating emission rates, and for using as inputs to the dispersion model. Hourly and annual emissions of volatile organic compounds (VOCs), particulate matter (PM), and exempt solvents (ES) were calculated for each permitted entity/ company in the database, according to equations given by TCEQ. Dispersion modeling was then conducted for 3 facility configurations (worst-case stack height, good practice stack height, and fugitive emissions), for urban and rural dispersion parameters, for 8-hour and 24-hour operating scenarios, and for 1-hour, 24-hour, and annual averaging times, for a total of 36 scenarios. The highest modeled concentrations were for the worst-case stack height, rural dispersion parameters, 24-hour operation scenario, and 1-hour averaging time. 108 specific chemical species, which are components of surface coatings, were identified as candidates for further health impacts review.
\end{abstract}

Keywords: Volatile Organic Compounds; Hazardous Air Pollutants; Surface Coating Facilities; Emissions; Dispersion Modeling

\section{Introduction}

Surface coating facilities apply decorative or protective coatings (paints, varnishes, lacquers) to substrates, which can include metals, wood, paper, plastic, and others. The coatings, in liquid or powder form, can be applied by a variety of methods, such as brushing, rolling, spraying, dipping and flow coating. After the coating is applied, the surface is air and/or heat dried to remove the volatile solvents from the coated surface [1]. Types of surface coating facilities include automobile refinishing shops and industrial facilities that apply coatings to products such as appliances, furniture, boilers, furnaces, pipes, cans, computers, and aircraft [2].

Surface coating facilities are major sources of volatile organic compounds (VOCs) in urban areas [3-5]. Surface coating facilities release VOCs when organic solvents in the coatings evaporate [6,7]. These VOCs can contribute to ground-level ozone formation, and many are hazardous air pollutants (HAPs) according to the US Clean Air Act, including xylene, ethylbenzene, and toluene. 
Several studies have evaluated the contribution of surface coating facilities to regional emission inventories [8-11]. In addition, a number of studies have examined methods of reducing emissions from surface coating facilities [6,12-17]. Wadden et al. (1995) estimated VOC emissions for a sheetfed offset printing facility [18]. McCarthy and Senser (2006) developed a numerical model for paint transfer and deposition in electrostatic air sprays [19]. No previous work, to our knowledge, has developed a comprehensive database to characterize surface coating facilities or conducted dispersion modeling to systematically characterize off-site impacts.

The work was performed for the Texas Commission on Environmental Quality (TCEQ), in order to provide information for updating the TCEQ permit by rule for Surface Coating Facilities. Project objectives were:

1) To develop a database of information regarding surface coating facilities in Texas;

2) To estimate maximum emission rates for various VOC species from surface coating facilities in Texas;

3) To conduct dispersion modeling to estimate off-site impacts from surface coating facilities.

\section{Methodology}

\subsection{Development of Surface Coating Facilities Database}

Data was collected from almost 300 TCEQ permit files authorizing surface coating facilities in Texas during 2006 and 2007. Surface coating permits by rule (PBRs) and new source review permits (NSRs) were reviewed for projects that were completed between 9/1/06 and $8 / 31 / 07$. This period was chosen as a fairly recent time, but one which would allow permit files to be complete/ closed. Projects were retained in the database that involved actual surface coating of items; projects involving abrasive blast alone, manufacture of coatings, making objects from a mold but not surface coating them, and printing alone were not included. The final databases thus contained 190 PBRs and 96 NSRs, for a total of 286 permits. The database included physical specifications of the surface coating facilities (stack parameters and building dimensions); facility location information; hours of operation; spray, drying, and air pollution control technology information; and coatings information (amount and type of coatings used, coating composition). The database was designed to include information important for estimating emission rates, and for using as inputs to the dispersion model.

\subsection{Estimation of Maximum VOC Emission Rates}

Emissions were calculated for each permitted entity/ company in the database. Hourly and annual emissions were calculated for volatile organic compounds (VOCs), particulate matter (PM), and exempt solvents (ES), according to equations given by TCEQ in "Painting Basics and Emission Calculations for TCEQ Air Quality Permit Applications" [20]. PM and ES were included, since some emissions from surface coating facilities occur in the form of particulates or solvent which are organics but have been excluded from the regulatory definition of VOCs. Emissions calculations accounted for transfer efficiency, overspray filter efficiency, PM fallout, and solvent flash off, as appropriate.

\subsection{Dispersion Modeling}

To estimate surface coating facility off-site impacts, dispersion modeling was conducted using the Gaussian dispersion model ISCST3 (ISC-AERMOD View, Lakes Environmental Version 5.1). Inputs to ISCST3 are discussed below.

\subsubsection{Source Information}

Three emission configurations were modeled, as listed in Table 1. These configurations were based on an evaluation of information contained in the database, as will be discussed later.

All sources were co-located at the origin of radial receptor grid $(0,0)$, to provide a worst-case scenario. The stacks were modeled as point sources exiting vertically, with velocity $53 \mathrm{ft} / \mathrm{sec}$ and ambient temperature, based on information from the database. BPIP (Building Profile Input Program) was run to account for building downwash for the worst-case stack.

Fugitive emissions were modeled as 5 circular area sources, 25' in diameter at heights of 5', 10', 15', 20', and 25'. All 5 circular area sources were modeled simultaneously, to represent emissions emanating from building doors, windows, and other openings of various heights. Information about specific locations and dimensions of building doors, windows, and other openings was not available in the permit files. The fugitive scenario was also used to represent outdoor facilities.

An emission rate of $1 \mathrm{lb} / \mathrm{hr}$ was used for each source.

Table 1. Emission configurations modeled.

\begin{tabular}{cccc}
\hline $\begin{array}{c}\text { Building } \\
\text { Configuration }\end{array}$ & $\begin{array}{c}\text { Building } \\
\text { Dimensions }\end{array}$ & Paint Booth Stack & Fugitives \\
\hline 1 & $\begin{array}{c}\text { Circular building, } \\
\text { 25' dia } \times \text { 25' height }\end{array}$ & $\begin{array}{c}\text { Worst-case stack, } \\
\text { 30' high, 1' diameter }\end{array}$ & None \\
& $\begin{array}{c}\text { Circular building, } \\
\text { 25' dia } \times \text { 25' height }\end{array}$ & $\begin{array}{c}\text { Good practice stack, } \\
\text { 40' high, 1' diameter }\end{array}$ & None \\
& $\begin{array}{c}\text { Circular building, } \\
25\end{array}$ & None dia $\times 25$ ' height & $\mathrm{X}$ \\
\hline
\end{tabular}


Model output values were later multiplied by factors to account for actual emission rates of specific chemical compounds. Both 8-hour (8 a.m. to 4 p.m.) and 24-hour operating scenarios were modeled.

\subsubsection{Meteorological Data}

- The meteorological data had wind direction aligned with the receptor radials. Directions ranged from $0^{\circ}$ to $350^{\circ}$ at $10^{\circ}$ increments.

- Five years of hourly meteorological data was provided by TCEQ staff.

\subsubsection{Receptor Grid/Terrain Elevations}

- Receptor locations were based on an origin of $(0,0)$.

- Receptors were located in radials from $0^{\circ}$ to $350^{\circ}$ at $10^{\circ}$ increments.

- The spacing of receptors in the radial direction was 100 feet $(30.5 \mathrm{~m})$.

- The extent of the receptors was from 100 - 1000 feet ( $30.5 \mathrm{~m}$ to $304.8 \mathrm{~m}$ ).

- The elevation of the receptors was set to 0 meters.

\subsubsection{Other Model Options}

- 1-hour and annual averaging times were used to facilitate comparison with TCEQ short-term and longterm Effects Screening Levels (ESLs), respectively. A 24-hour averaging time was also modeled.

- Regulatory default mode was used.

- Runs were conducted using rural and urban dispersion parameters.

- It was assumed that no significant removal occurs due to wet deposition, dry deposition, chemical reaction (exponential decay), or gravitational setting.

- The PLOTFILE option was selected for each source group and averaging times.

\section{Results and Discussion}

\subsection{Summary of Surface Coating Facility Characterization Data}

As mentioned above, the database included 286 surface coating facility permits. The number of values for various parameters varied, since some permits contained incomplete data. This section summarizes surface coating facility information collected from the database.

\subsubsection{Stack Parameters}

Figures 1-6 summarize stack flow rate, diameter, velocity, height, temperature, and stack height-to-building height ratio values. The $\mathrm{n}$ value in parentheses after each figure caption indicates the number of values of that parameter that were found in the database, and used to create the histogram. Verbal summaries of the stack parameter

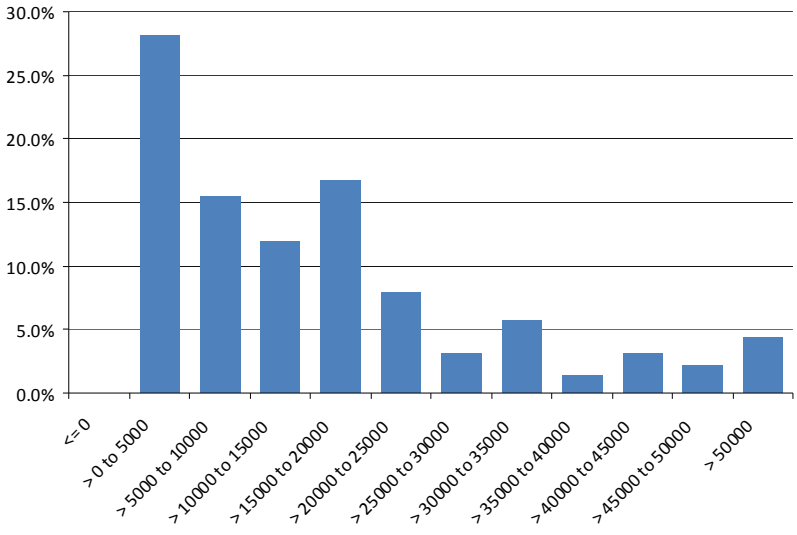

Figure 1. Summary of stack flow rates $\left(\mathrm{ft}^{3} / \mathrm{min}\right)(\mathrm{n}=227)$.

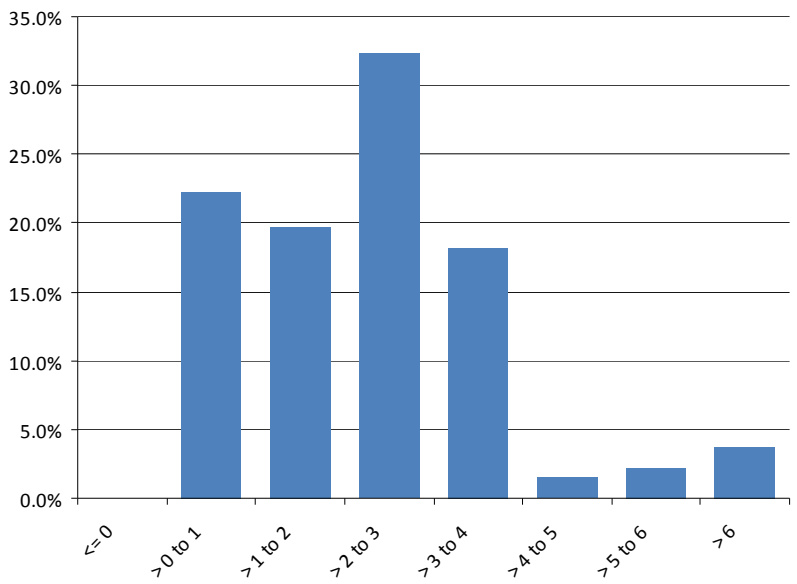

Figure 2. Summary of stack diameters $(\mathrm{ft})(\mathrm{n}=\mathbf{2 6 9})$.

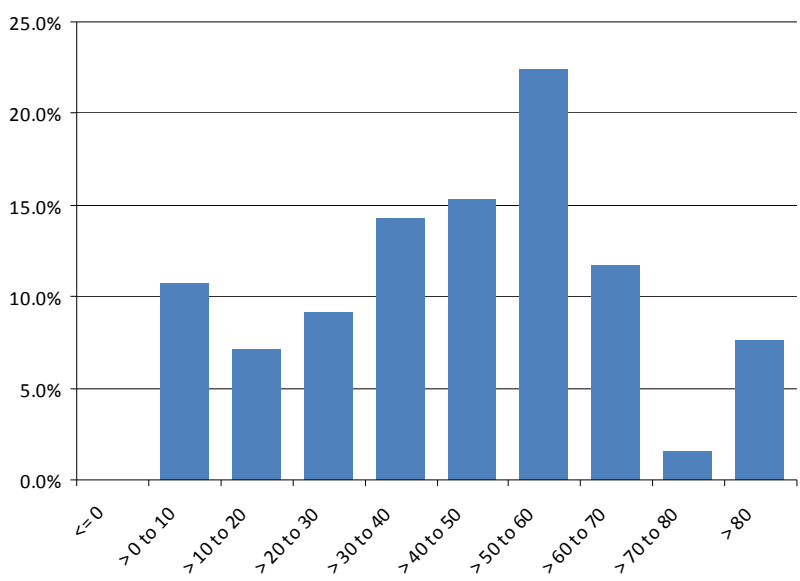

Figure 3. Summary of stack velocities $(\mathrm{ft} / \mathrm{sec})(\mathrm{n}=196)$.

data are provided below:

- Stack flow rate: The histogram peak for stack flow rate occurs in the $0-5000 \mathrm{ft}^{3} / \mathrm{min}$ category, representing $28 \%$ of facilities. Over $70 \%$ of facilities have a stack flow rate of $20,000 \mathrm{ft}^{3} / \mathrm{min}$ or less.

- Stack diameter: The largest number of facilities (32\%) 


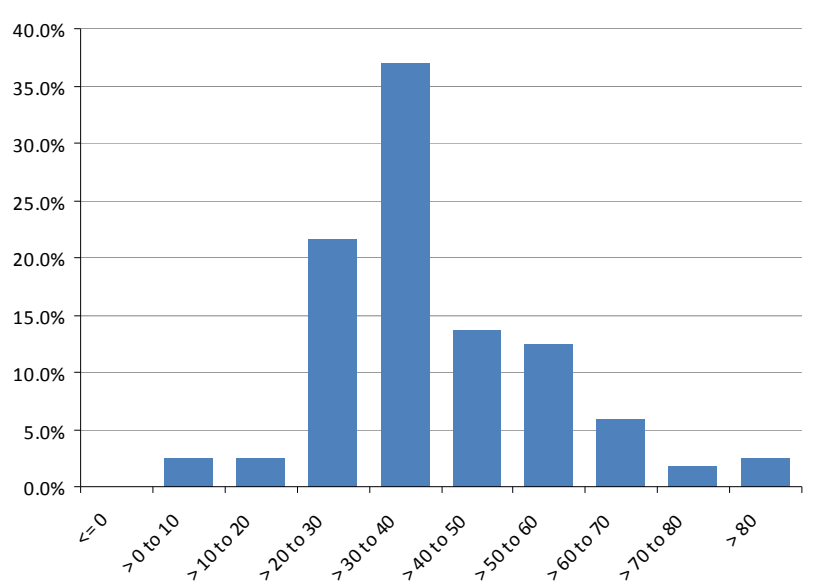

Figure 4. Summary of stack heights $(\mathrm{ft})(\mathrm{n}=440)$.

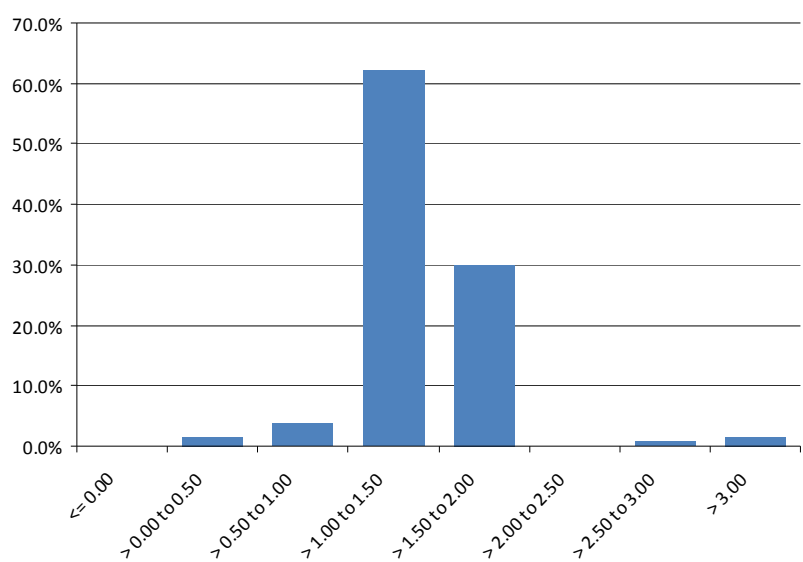

Figure 5. Summary of stack height to building height ratios $(\mathbf{n}=130)$.

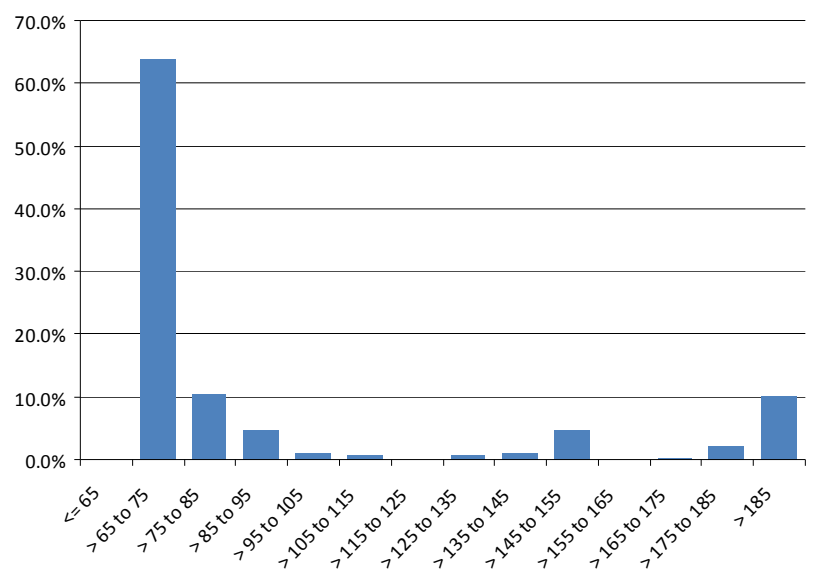

Figure 6. Summary of stack exit temperatures $\left({ }^{\circ} \mathrm{F}\right)(\mathrm{n}=$ 276).

have stacks in the $>2$ - 3 foot range, with around $20 \%$ of stacks falling in each of the $0-1,>1-2$, and $>3-4$ foot categories. $83 \%$ of the stacks have diameters 1 foot or greater.
- Stack velocity: The peak of the velocity histogram occurs at 50 - $60 \mathrm{ft} / \mathrm{sec}$ (22\% of facilities).

- Stack height: The peak of the stack height histogram occurs in the $>30$ - $40 \mathrm{ft}$ range, representing $37 \%$ of facilities. The average stack height is $41 \mathrm{ft}$.

- Stack height to building height ratio: $92 \%$ of the facilities have a stack height/building height ratio of 1.2 or greater. Good practice stack height is at least 1.5 times the building height to prevent building downwash. The average stack height to building height ratio was 1.51 .

- Stack temperature: $70 \%$ of facilities operate approximately at ambient temperatures of $68^{\circ} \mathrm{F}-80^{\circ} \mathrm{F}$. All other facilities operate at higher temperatures, likely representing use of a drying oven.

- Number of stacks: Of the facilities for which stack information was available, 78 (52\%) had one stack, 32 (21\%) had 2 stacks, and 41 (27\%) had 3 or more stacks.

Ground-level concentrations tend to increase as plume rise decreases. Since most surface coating facilities release emissions at ambient temperatures, their plume rise is dominated by momentum, not buoyancy. Momentum plume rise decreases when stack diameter and velocity decrease, since it is proportional to $\left(V_{s} D_{s}\right)^{2 / 3}$ for stable meteorological conditions, and $\mathrm{V}_{\mathrm{s}} \mathrm{D}_{\mathrm{s}}$ for unstable/neutral meteorological conditions. Thus, a worst-case stack would have a small diameter and velocity.

$83 \%$ of the stacks had diameters 1 foot or greater. A 1 -ft diameter thus represents a conservative worst-case likely to occur. The histogram peak for stack flow rate occurs in the $0-5000 \mathrm{ft}^{3} /$ min category, representing $28 \%$ of facilities. Choosing a flow rate value of $2500 \mathrm{ft}^{3} / \mathrm{min}$ in the middle of the category, along with a 1 foot diameter stack, gives a calculated velocity of $53 \mathrm{ft} / \mathrm{sec}$, which is within the histogram peak for stack velocity.

$92 \%$ of the facilities had a stack height/building height ratio of $\geq 1$. 2 . Thus, a stack height/building height ratio of 1.2 seems to be a worst case that is reasonably likely to occur. Since the building height was chosen to be 25', a 30 ' stack was chosen as a worst-case stack height.

Good practice stack height is $\geq 1.5$ times the building height to prevent building downwash. The average stack height to building height ratio was 1.51 . Since the building height was chosen to be 25', a stack height of $1.5 \times$ $25^{\prime}=40^{\prime}$ (rounded up to the nearest tens of feet) was chosen for good practice/typical stack height.

In summary, based on the above information, it was decided that 2 cases would be modeled: a worst-case stack with height 30 feet; and good practice/typical stack with height 40 feet. Both stacks would have diameter $1 \mathrm{ft}$, flow rate $2500 \mathrm{ft}^{3} / \mathrm{min}$, and resulting velocity $53 \mathrm{ft} / \mathrm{sec}$.

The stacks were placed at the center of the building at 
$(0,0)$. The stacks were modeled as point sources exiting vertically. From the data summary, virtually all stacks for which information was available exited vertically. In only isolated cases (4) was there a stack that was capped or exited horizontally.

For the case with worst-case stack height, building downwash needed to be considered. BPIP (Building Profile Input Program) was used to calculate values needed as inputs to the building downwash algorithm.

\subsubsection{Building Dimensions and Configurations}

Figures 7-9 summarize building height, length, and width values from the database. $48 \%$ of buildings have a height between 20 - $30 \mathrm{ft}$, with an average height of 27 feet. The histogram peaks for both building length and width occur in the 0 - $50 \mathrm{ft}$ category, representing 23\% and $31 \%$ of facilities, respectively. Of the buildings with dimensions that fall in the 0 - 50 foot range, the average building lengths and widths are $28.5 \mathrm{ft}$ and $25.3 \mathrm{ft}$, respectively.

A previous TCEQ study showed that worst case downwash occurs when all three building dimensions are equal. Instead of modeling a cubic building, we modeled a cylindrical building with equal diameter and height, so that the projected length/width of the building is the same in all directions. Based on the database building dimension information, a circular building 25' in diameter with 25 ' height was chosen for modeling.

Table 2 summarizes emission release configuration information obtained from the database.

Together, the one stack/no fugitives and one stack with fugitives configurations represent $52 \%$ (78 of 151) of the facilities in the database for which building configuration information was available.

Two of the facilities in the table above with 2 or more stacks also had ovens. Since no facilities with one stack had ovens, and only 2 facilities with 2 or more stacks had

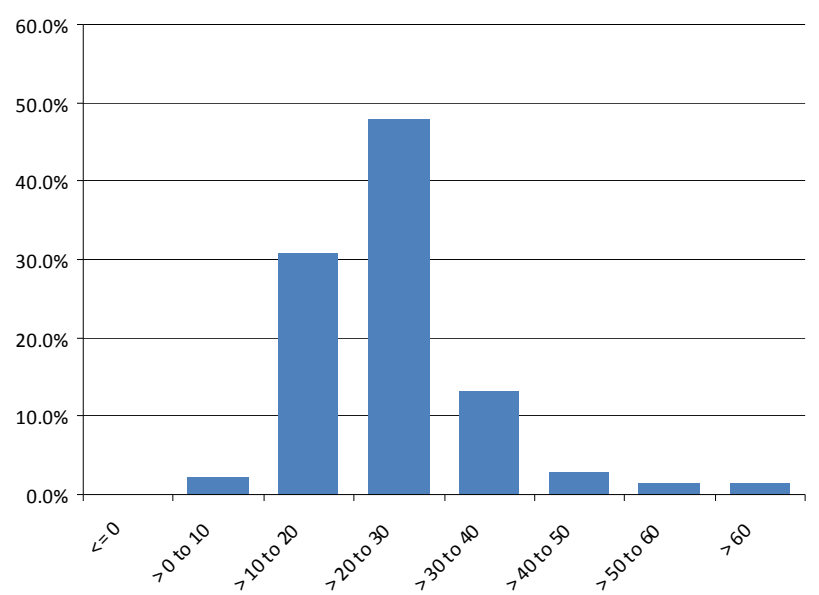

Figure 7. Summary of building heights $(\mathrm{ft})(\mathrm{n}=136)$.

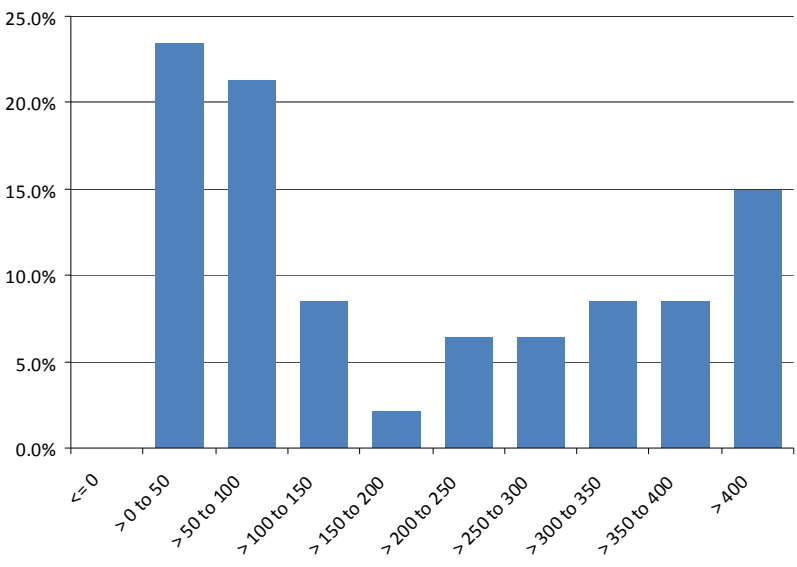

Figure 8. Summary of building lengths $(\mathrm{ft})(\mathrm{n}=47)$.

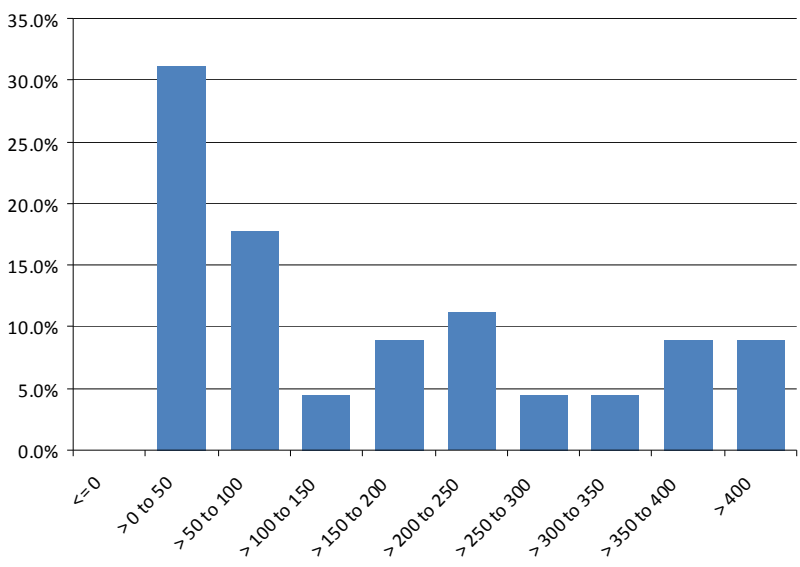

Figure 9. Summary of building widths $(\mathrm{ft})(\mathrm{n}=45)$.

Table 2. Summary of emission release configurations.

\begin{tabular}{cccc}
\hline \multicolumn{2}{c}{ Emission Release Configuration } & Total \\
\hline 1 stack & no oven & no fug & 76 \\
1 stack & oven & no fug & NA \\
1 stack & no oven & fug & 2 \\
1 stack & oven & fug & NA \\
2 stacks & no oven & fug & 11 \\
$>2$ stacks & no oven & fug & 11 \\
2 stacks & no oven & no fug & 21 \\
$>2$ stacks & no oven & no fug & 30 \\
& & Total & 151 \\
\hline
\end{tabular}

ovens, modeling a separate building configuration with an oven stack was not warranted.

Based on information from Table 2, 2 emission release configurations were chosen for modeling: a building with one stack, and the same building with fugitives. 


\subsubsection{Hours of Operation}

As shown in Figure 10, 44\% of facilities are permitted to operate 24 hours a day. Another $20 \%$ of facilities operate 6 - 9 hours a day, representing the histogram category with the second highest peak. Within the 6 - 9-hour category, most of the facilities operate 8 hours. Thus, both 24-hour and 8-hour operating scenarios were chosen for modeling.

\subsubsection{Distance to Property Line and Nearest Off-Site Receptor}

As shown in Figure 11, only 14\% of facilities have a distance to the property line 50 feet or less. Almost a third of facilities have a distance to the property line in the range $>50$ - 100. These distances could be used in conjunction with dispersion modeling output, discussed later, to determine whether health impacts are likely to occur past the property line.

As shown in Figure 12, 28\% of facilities have a distance to the nearest off-site receptor of $\leq 250 \mathrm{ft}$. Almost a third of facilities have a distance to the nearest off-site

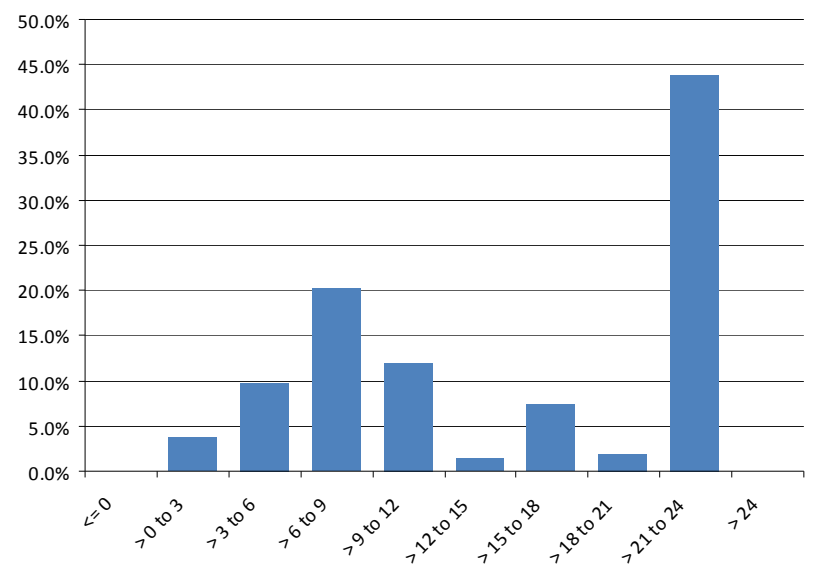

Figure 10. Summary of hours of operation $(n=217)$.

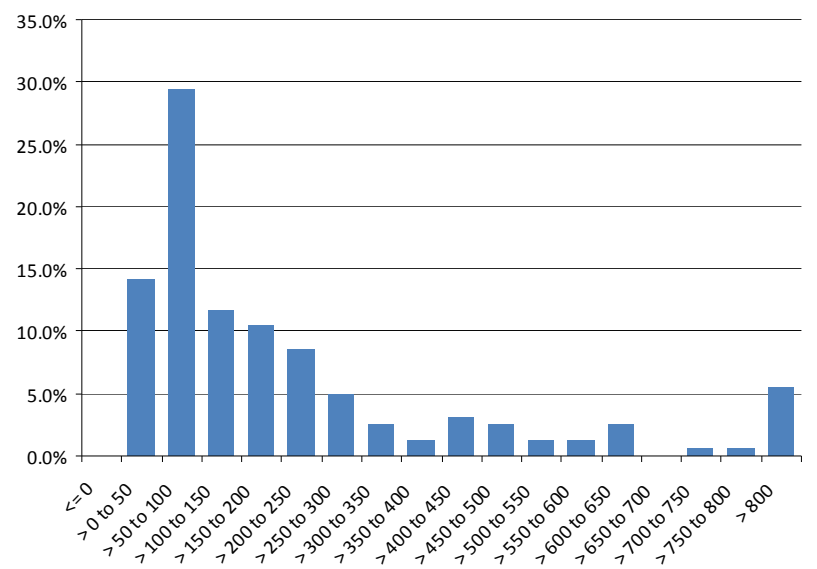

Figure 11. Summary of distance to nearest property line (ft) $(n=163)$. receptor $>250$ - $500 \mathrm{ft}$. These distances could be used in conjunction with dispersion modeling output to determine whether health impacts are likely to occur at nearby receptors.

\subsubsection{Spray Information}

Tables 3 and 4 summarize spray type and object shape information obtained from the database. This information was used in the emission calculations discussed in the next section.

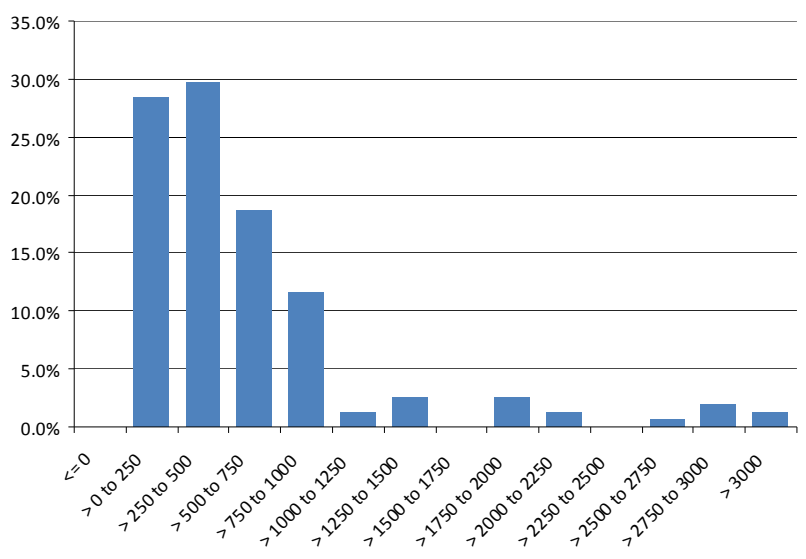

Figure 12. Summary of distance to nearest offsite receptor (ft) $(\mathbf{n}=155)$.

Table 3. Summary of spray type information $(n=220)$.

\begin{tabular}{cc}
\hline Spray Type & Usage Frequency-Percent \\
\hline Aerosol \& Air Atomized Spray & 3.2 \\
Airless Spray & 17.7 \\
HVLP & 20.5 \\
Brush & 1.4 \\
Dip & 6.4 \\
Electrostatic Air Atomized & 1.8 \\
Air Assisted & 0.9 \\
Flow Coat & 0.5 \\
Misc./Unspecified Spray & 45.5 \\
\hline
\end{tabular}

Table 4. Summary of object shape information $(n=235)$.

\begin{tabular}{cc}
\hline Object Shape & Frequency (\%) \\
\hline Flat Surface & 43.8 \\
Table Leg & 23.0 \\
Bird Cage & 7.2 \\
Two or Three Shapes & 12.3 \\
Miscellaneous & 13.6 \\
\hline
\end{tabular}


Figures 13-15 summarize spray time, max. hourly spray rate, and number of application station information.

\subsubsection{Drying Information}

Figures 16 and 17 summarize database values of time in

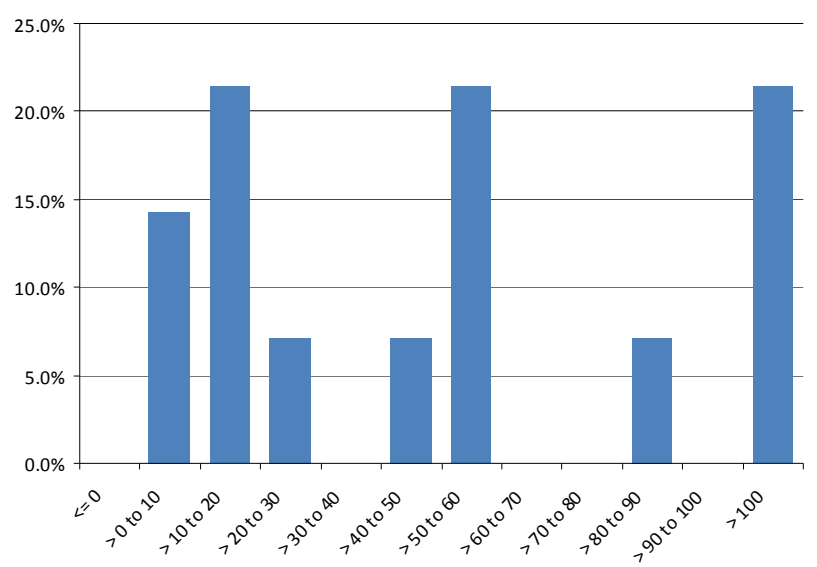

Figure 13. Summary of spray times $(\mathrm{min})(\mathrm{n}=14)$.

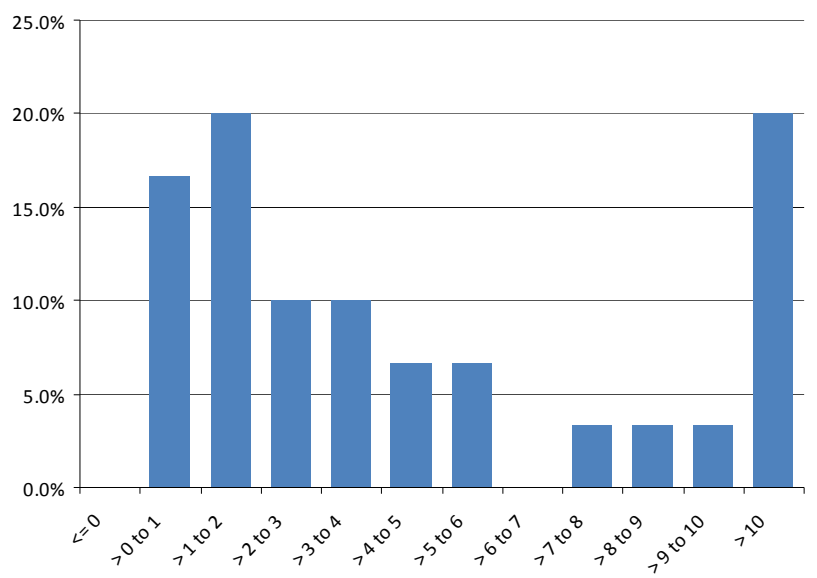

Figure 14. Summary of max. hourly spray rates (gal/hr) (n $=30$ ).

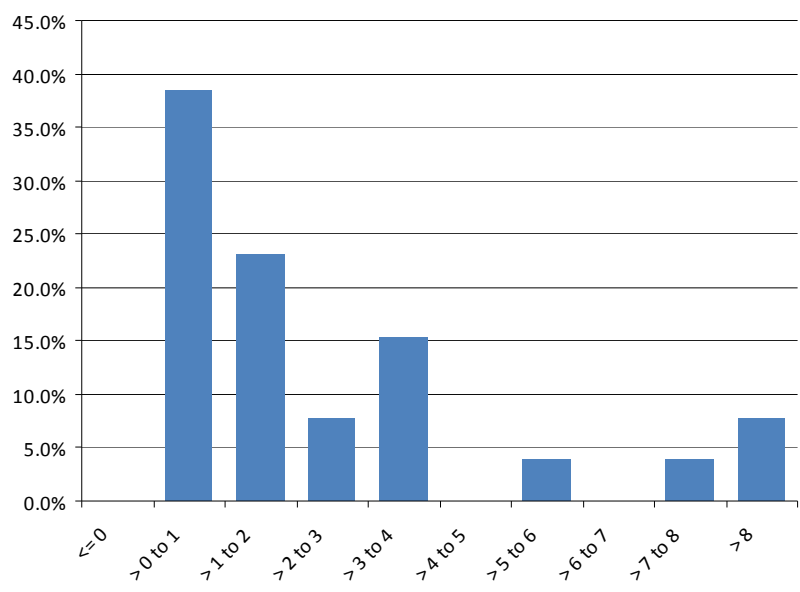

Figure 15. Summary of no. of application stations $(\mathbf{n}=\mathbf{2 6})$. drying booth and drying oven heat input values, respectively. Only 1 time on conveyer value was available $(0.5$ min), and only 3 time in oven values were available (90 min, $180 \mathrm{~min}$, and $180 \mathrm{~min}$ ). This information was used in the emission calculations discussed later.

Only one time on conveyor value was available from the database ( $0.5 \mathrm{~min})$, and only 3 time in oven values were available (90 min, $180 \mathrm{~min}$, and $180 \mathrm{~min}$ ).

\subsubsection{Control Information}

Figures 18-20 summarize parameters related to filters used to control particulate emissions: minimum face velocity, dry filter efficiency, and dry filter face velocity. In addition, 6 facilities are shown in the database as using water wash/wet scrubber systems. This information was used in the emission calculations discussed later.

\subsubsection{Solvent Information}

Figures 21-23 summarize solvent information used in

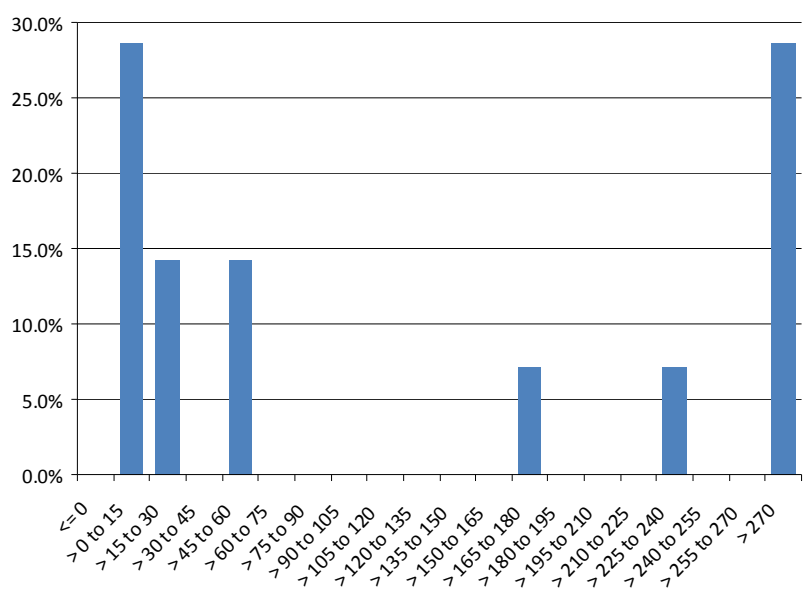

Figure 16. Summary of time in booth, $\min (n=14)$.

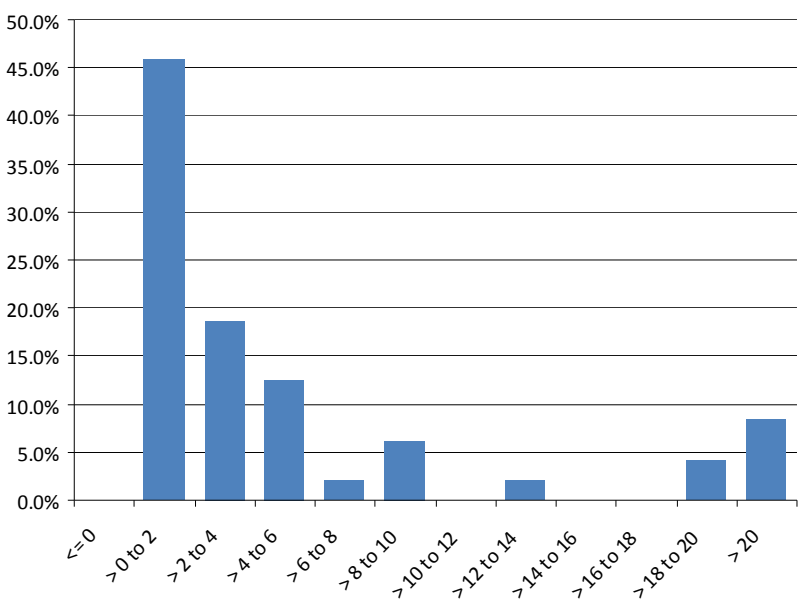

Figure 17. Summary of maximum heat input, MMBtu/hr (n = 48). 


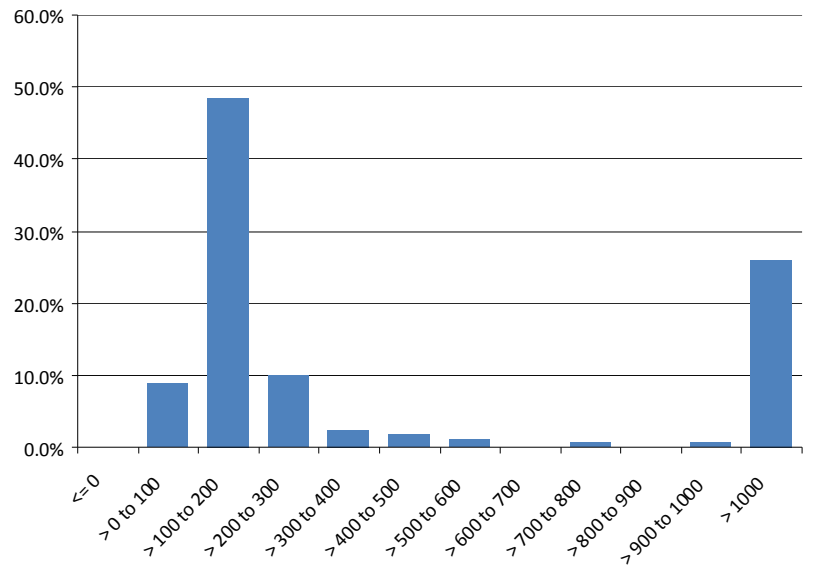

Figure 18. Summary of minimum face velocity, $\mathrm{ft} / \mathrm{min}(\mathrm{n}=$ 169).

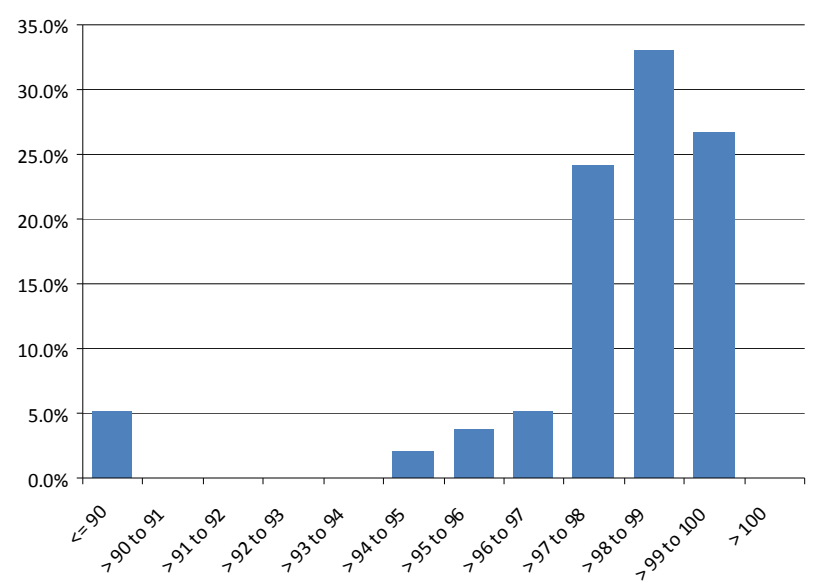

Figure 19. Summary of dry filter efficiency $(n=236)$.

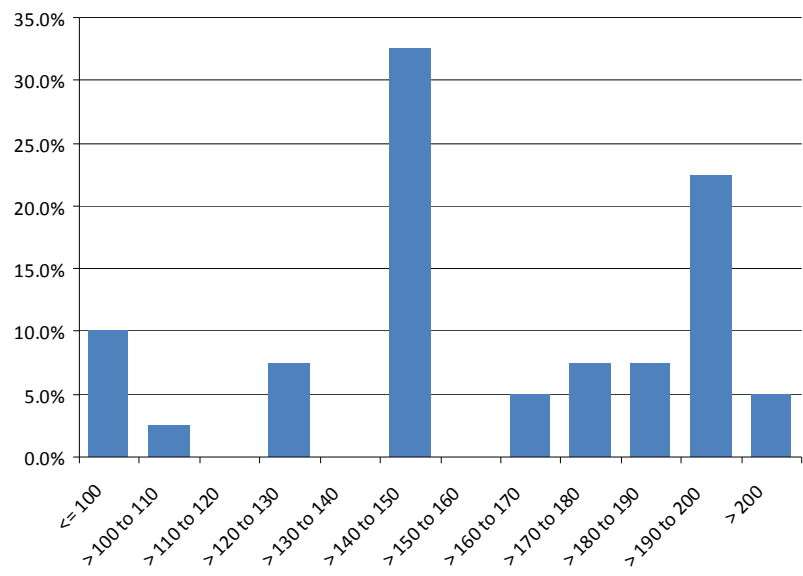

Figure 20. Summary of dry filter face velocity, $\mathbf{f t} / \mathrm{min}(\mathrm{n}=$ 40).

emission calculations.

Table 5 shows the 20 components used at the most facilities. As shown, xylene is the component used at the most facilities.

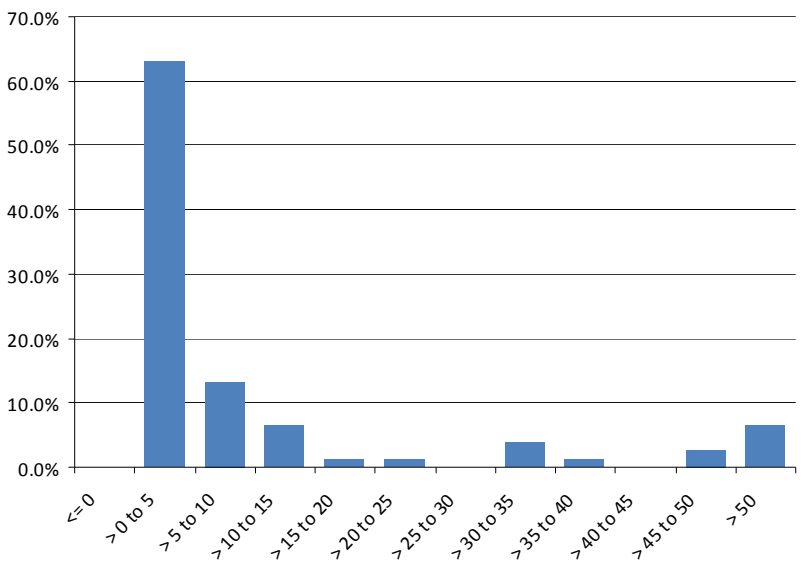

Figure 21. Summary of hourly coating use, gal/hr $(n=76)$.

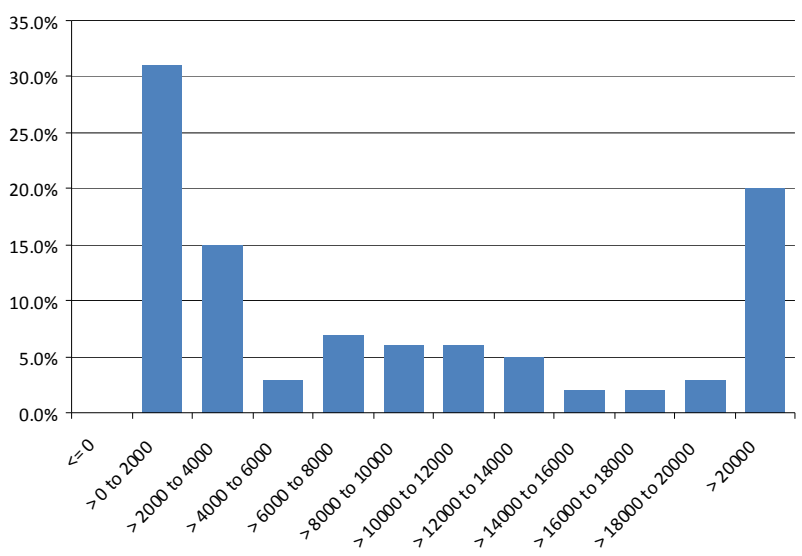

Figure 22. Summary of annual coating use, gal/yr $(n=100)$.

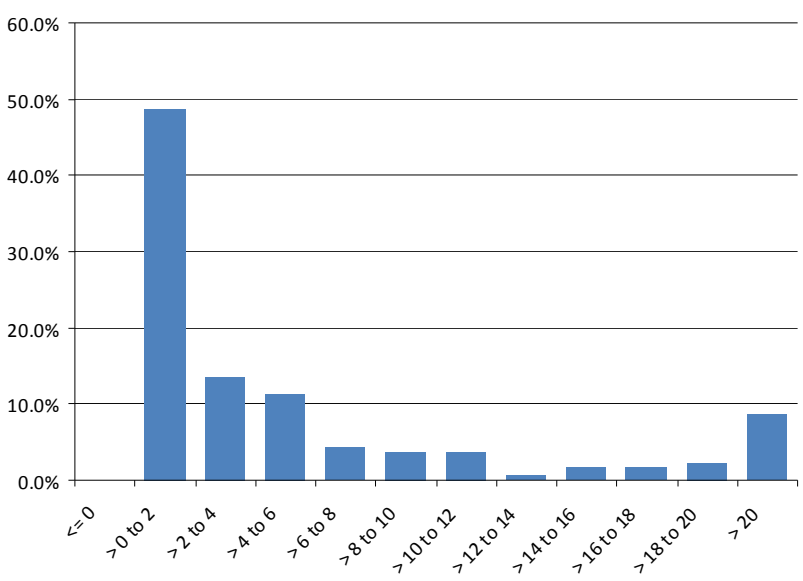

Figure 23. Summary of number of coatings/solvents used per project $(\mathbf{n}=185)$.

\subsection{Maximum VOC Emission Rates}

Of the 199 coating/solvent components identified in the database, the 21 chemicals with the maximum ratios of emissions to short-term (1-hour) effect screening levels (ESLs) are shown in Table 6. These are likely to be the 
Table 5. Number of facilities using each component.

\begin{tabular}{cc}
\hline Component & No. of facilities \\
\hline Xylene & 87 \\
Ethylbenzene & 78 \\
Toluene & 61 \\
Titanium dioxide & 58 \\
Methyl isobutyl ketone & 52 \\
Magnesium silicate & 49 \\
Methyl n-amyl ketone & 46 \\
n-tateebutyl aB & 45 \\
Quartz & 43 \\
yl ethyl ketoneMeth & 43 \\
Acetone & 42 \\
Glycol Ether & 41 \\
1-Butanol & 39 \\
Light aromatic hydrocarbons & 38 \\
1,2,4-Trimethylbenzene & 38 \\
Carbon black & 36 \\
1-Methoxyl-2-propanol acetate & 34 \\
Isopropyl alcohol & 34 \\
Naphtha & 29 \\
V. M. \& P. Naphtha & 28 \\
\hline
\end{tabular}

N/A Not applicable. chemicals of most concern in terms of health impacts; this must be confirmed taking into account emission configurations (paint booths emissions typically emitted via a stack, and conveyor emissions released as fugitives) via dispersion modeling, as discussed in the next section. The TCEQ uses ESLs in their air permitting process to evaluate air dispersion modeling's predicted impacts. If modeled concentrations of a pollutant do not exceed the screening level, adverse health or welfare effects are not expected. If modeled concentrations of a pollutant exceed the screening levels, it does not necessarily indicate a problem but rather triggers a more in-depth review.

\subsection{Dispersion Modeling Results}

\subsubsection{Pollution Concentration Isopleths}

Dispersion modeling was conducted for the 3 configurations (worst-case stack height, good practice stack height, and fugitive emissions), for urban and rural dispersion parameters, for 8-hour and 24-hour operating scenarios, and for 1-hour, 24-hour, and annual averaging times, for a total of $2 \times 3 \times 2 \times 3=36$ scenarios. All 36 concentration isopleths are available from the authors. Figures 2426 show plots with the highest concentrations for each configuration. The plots show the maximum 1-hour concentrations at each receptor over the 5 years of meteorological data modeled. Vertical and horizontal axes have units of $\mathrm{m}$.

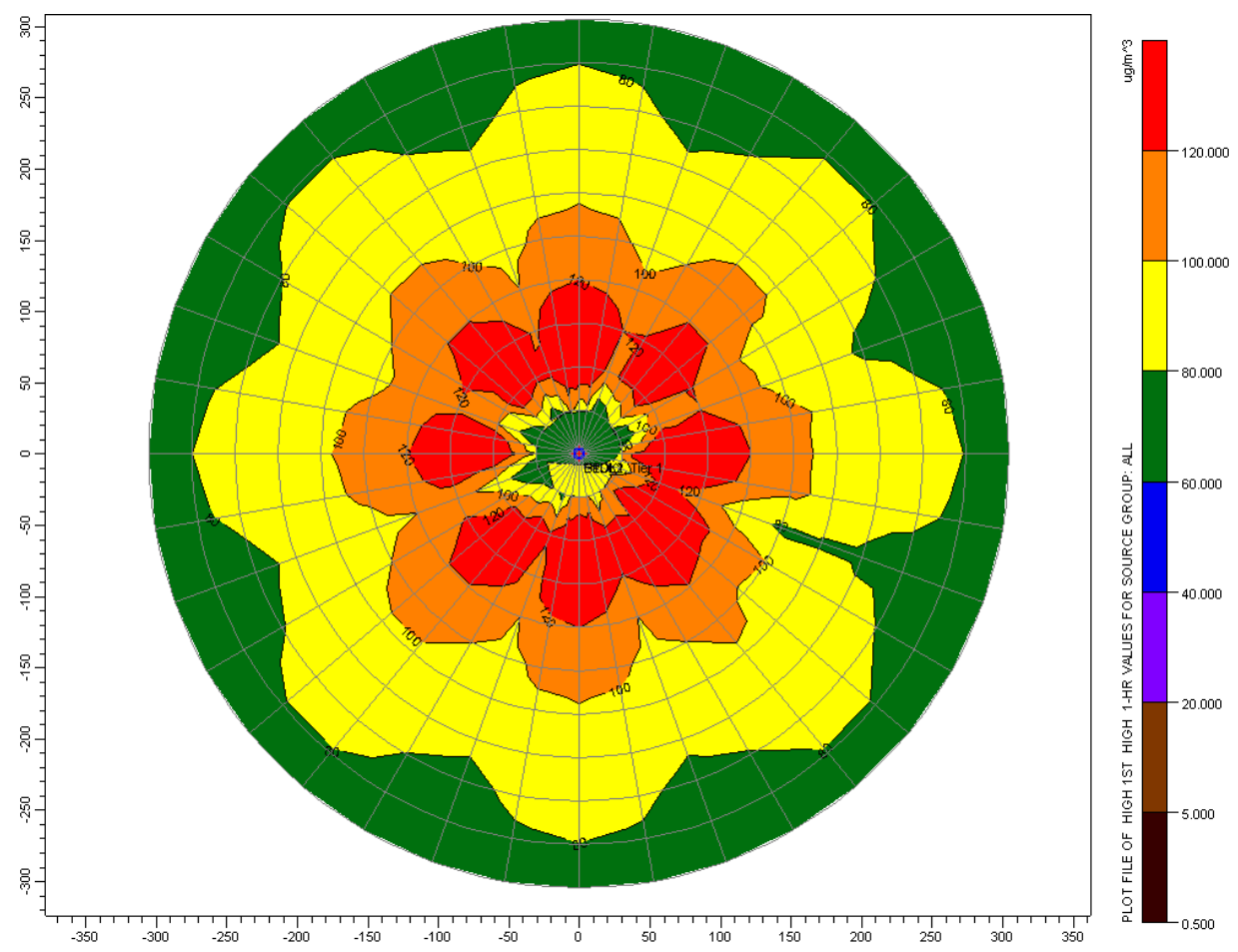

Figure 24. Concentrations for worst-case stack configuration, rural dispersion parameters, 24-hour operation, 1-hour averaging time. 

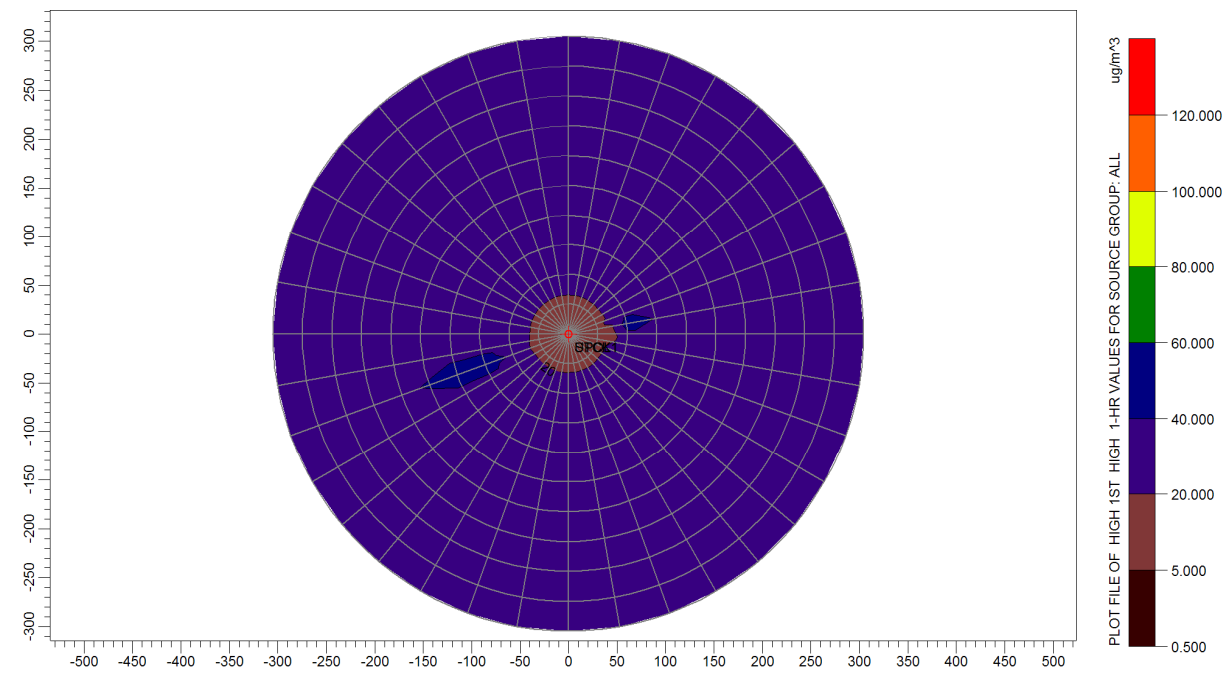

Figure 25. Concentrations for good practice stack configuration, urban dispersion parameters, 24-hour operation, 1-hour averaging time.
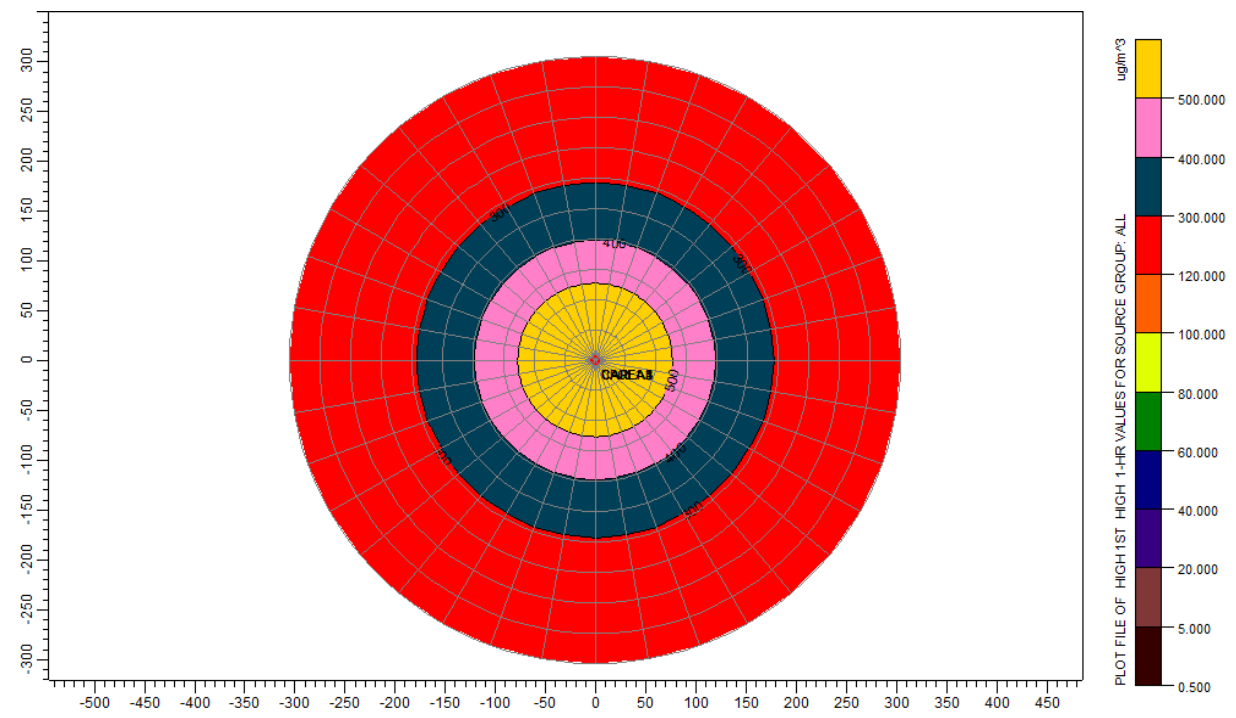

Figure 26. Concentrations for fugitive configuration, rural dispersion parameters, 24-hour operation, 1-hour averaging time.

The impact of building configuration, averaging time, operating scenario, and rural vs. urban terrain on groundlevel concentrations are discussed below.

Building configuration. As expected, the worst-case stack produced higher ground-level concentrations than the good practice stack. The fugitive configuration produced higher ground-level concentrations than either stack configuration, most likely because the fugitive source is located nearer the ground.

Averaging time. As expected, 1-hour average concentrations were higher than 24-hour average concentrations, which were in turn higher than annual average concentrations. Variations in wind direction produce lower concentrations as averaging time increases.

Operating scenario. The 24-hour operating scenario gave higher concentrations than the 8-hour operating scenario for the worst-case stack; for the good-practice stack and fugitive building configurations, however, both operating scenarios produced the same concentrations. The fact that the 8-hour and 24-hour operating scenarios produced the same concentrations indicates that meteorological conditions producing worst-case concentrations occurred from 8 a.m.-4 p.m., during 8-hour operation. We believe that the 8-hour and 24-hour operating scenarios gave different concentrations for the worst-case stack configuration because this was the only configuration for which the building downwash program BPIP was run.

Rural vs. urban terrain. For the stack configurations, at some receptor locations urban dispersion parameters 
Table 6. Coating/solvent components with highest emission to effect screening level ratios.

\begin{tabular}{|c|c|c|c|c|c|}
\hline \multirow{2}{*}{ Component } & \multicolumn{2}{|c|}{ Maximum Emission Rate E, lb/hr } & \multirow{2}{*}{$\begin{array}{l}\text { Short-Term } \\
\text { ESL, } \mu \mathrm{g} / \mathrm{m}^{3}\end{array}$} & \multicolumn{2}{|c|}{ E/ESL } \\
\hline & Paint Booth & Conveyor & & Paint Booth & Conveyor \\
\hline Quartz & 56.09 & N/A & 10 & 5.61 & N/A \\
\hline 4,4'-diphenylomethane diisocyanate & 2.55 & 0.56 & 0.5 & 5.1 & 1.12 \\
\hline Diphenylmethane diisocyanate polymer & 10.22 & N/A & 3 & 3.41 & N/A \\
\hline Hexamethylene diisocyanate & 10.44 & N/A & 4 & 2.61 & N/A \\
\hline Talc & 37.19 & N/A & 20 & 1.86 & N/A \\
\hline Zinc dust & 91.88 & N/A & 50 & 1.84 & N/A \\
\hline Hydrated iron oxide & 76.34 & N/A & 50 & 1.53 & N/A \\
\hline Clay (kaolin) & 18.98 & N/A & 20 & 0.95 & N/A \\
\hline Bisphenol A diglycidyl ether & 12.99 & N/A & 14 & 0.93 & N/A \\
\hline C18 unsaturated dimers, polymer w/BPA & 38.04 & N/A & 50 & 0.76 & N/A \\
\hline Potassium silicate & 37.72 & N/A & 50 & 0.75 & N/A \\
\hline Phenol novalac & 36.43 & N/A & 50 & 0.73 & N/A \\
\hline Butyl acetate & 25.5 & 9.09 & 36 & 0.71 & 0.25 \\
\hline Tremolite (non-asbestiform) & 12.99 & N/A & 20 & 0.65 & N/A \\
\hline Barium sulfate & 31.09 & N/A & 50 & 0.62 & N/A \\
\hline Methyl n-amyl ketone & 19.58 & 4.54 & 32 & 0.61 & 0.14 \\
\hline Paraffin waxes, hydrocarbon waxes & 11.59 & N/A & 20 & 0.58 & N/A \\
\hline Epoxy resin & 26.65 & N/A & 50 & 0.53 & N/A \\
\hline Chromium oxide & 0.53 & N/A & 1 & 0.53 & N/A \\
\hline p-Toluenesulfonyl isocyanate & 0.53 & N/A & 1 & 0.53 & N/A \\
\hline Chromium III (as Cr) & 0.53 & N/A & 1 & 0.53 & N/A \\
\hline
\end{tabular}

N/A: Not applicable.

gave higher concentrations, and in some cases rural gave higher. For the fugitive configuration, rural dispersion parameters gave higher concentrations. When worst-case stack concentrations were added to fugitive concentrations, rural dispersion parameters gave higher maximum values for each pollutant, as shown in Table 7. However, when good-practice stack concentrations were added to fugitive concentrations, urban dispersion parameters gave higher maximum values for each pollutant.

\subsubsection{Coating Component Species Warranting Further Review}

To determine which pollutants would warrant a more indepth health impacts evaluation, pollutant specific emission rates (E) and effects screening levels (ESLs) were applied in the form of E/ESL on a source-by-source basis to the unit concentration at each receptor; then the contribution from each source at each receptor was summed. In other words, the following sum was evaluated for each chemical species $\mathrm{i}$ at each receptor location $\mathrm{j}$ :

$$
\begin{aligned}
\mathrm{SUM}= & \left(\mathrm{E}_{\mathrm{i} \text { paintbooth }}\right) / \mathrm{ESL}_{\mathrm{i}} *\left(\mathrm{C}_{\mathrm{j} \text { paintbooth max }}\right) \\
& +\left(\mathrm{E}_{\mathrm{i} \text { conveyor }}\right) / \mathrm{ESL}_{\mathrm{i}} *\left(\mathrm{C}_{\mathrm{j} \text { fugitives max }}\right)
\end{aligned}
$$

where

$\mathrm{C}_{\mathrm{j} \text { paintbooth max }}$ is the maximum modeled 1-hour concentration for the worst-case or good-practice stack configuration at receptor location $\mathrm{j}$.

$\mathrm{C}_{\mathrm{j} \text { fugitives max }}$ is the maximum modeled 1-hour concentration for the fugitive configuration at receptor location j.

$\mathrm{ESL}_{\mathrm{i}}$ is the short-term (1-hour) effect screening level for pollutant $\mathrm{i}$, i,

$E_{i \text { paintbooth }}$ is the maximum stack emission of pollutant

$E_{i \text { conveyor }}$ is the maximum fugitive emission of pollutant i.

Only concentrations for the 1-hour averaging time 
Table 7. Maximum SUM values for worst-case stack + fugitives.

\begin{tabular}{|c|c|c|c|c|c|c|c|}
\hline \multirow[b]{2}{*}{ Compound } & \multirow[b]{2}{*}{$\begin{array}{l}\text { Short-Term } \\
\text { ESL, } \mathrm{mg} / \mathrm{m}^{3}\end{array}$} & \multicolumn{2}{|c|}{ Rural 8-hour operation } & \multicolumn{2}{|c|}{ Rural 24-hour operation } & \multicolumn{2}{|c|}{ Urban 24-hour operation } \\
\hline & & $\begin{array}{l}\text { Max. Sum of } \\
(\mathrm{E} / \mathrm{ESL})^{*} \mathrm{C}, \\
\mathrm{lb} / \mathrm{hr}\end{array}$ & $\begin{array}{l}\text { No. of Sum } \\
\text { Values }>1\end{array}$ & $\begin{array}{c}\text { Max. Sum of } \\
(\mathrm{E} / \mathrm{ESL})^{*} \mathrm{C} \\
\mathrm{lb} / \mathrm{hr}\end{array}$ & $\begin{array}{l}\text { No. of Sum } \\
\text { Values }>1\end{array}$ & $\begin{array}{c}\text { Max. Sum of } \\
(\mathrm{E} / \mathrm{ESL})^{*} \mathrm{C} \text {, } \\
\mathrm{lb} / \mathrm{hr}\end{array}$ & $\begin{array}{l}\text { No. of Sum } \\
\text { Values }>1\end{array}$ \\
\hline 1,3,5-Trimethylbenzene & 1250 & 1.5 & 128 & 1.5 & 163 & 1.5 & 37 \\
\hline 2,4-pentanedione & 40 & 4.7 & 360 & 5.1 & 360 & 4.5 & 360 \\
\hline 2-Butoxy ethanol & 210 & 14.4 & 360 & 14.9 & 360 & 14.1 & 360 \\
\hline 2-Butoxyethyl acetate & 310 & 6.0 & 360 & 6.3 & 360 & 5.9 & 360 \\
\hline 4,4'-diphenylomethane diisocyanate & 0.5 & 1287 & 360 & 1342 & 360 & 1255.4 & 360 \\
\hline Acrylic polymer A & 50 & 12.2 & 360 & 13.2 & 360 & 11.6 & 360 \\
\hline Alkyl phthalate & 50 & 16.6 & 360 & 17.9 & 360 & 15.8 & 360 \\
\hline Aluminum flakes & 50 & 9.9 & 360 & 10.6 & 360 & 9.4 & 360 \\
\hline Aluminum oxide & 50 & 5.4 & 360 & 5.8 & 360 & 5.1 & 360 \\
\hline Aluminum silicate & 50 & 24.0 & 360 & 25.9 & 360 & 22.9 & 360 \\
\hline Anthophyllite (non-asbestiform) & 20 & 3.1 & 353 & 3.3 & 360 & 2.9 & 360 \\
\hline Antigorite & 20 & 17.4 & 360 & 18.8 & 360 & 16.6 & 360 \\
\hline Barium chromate & 0.1 & 13.3 & 360 & 14.4 & 360 & 12.7 & 360 \\
\hline Barium metaborate hydrate & 50 & 9.3 & 360 & 10.0 & 360 & 8.81 & 360 \\
\hline Barium sulfate & 50 & 84.6 & 360 & 91.3 & 360 & 80.6 & 360 \\
\hline Benzyl alcohol & 500 & 3.0 & 342 & 3.1 & 360 & 2.9 & 360 \\
\hline Bisphenol A diglycidyl ether & 14 & 126.2 & 360 & 136.2 & 360 & 120.3 & 360 \\
\hline Butoxyethoxyethanol & 1060 & 2.8 & 330 & 3.0 & 360 & 2.7 & 218 \\
\hline Butyl acetate & 36 & 230.1 & 360 & 237.7 & 360 & 225.8 & 360 \\
\hline Butyl alcohol & 610 & 5.4 & 360 & 5.5 & 360 & 5.33 & 360 \\
\hline $\begin{array}{l}\text { C18 unsaturated dimers, polymer } \\
\text { w/BPA and ech }\end{array}$ & 50 & 103.5 & 360 & 111.7 & 360 & 98.6 & 360 \\
\hline Calcium carbonate & 50 & 28.8 & 360 & 31.1 & 360 & 27.5 & 360 \\
\hline Calcium magnesium carbonate & 50 & 9.9 & 360 & 10.6 & 360 & 9.4 & 360 \\
\hline Ceramic metals and wares & 50 & 31.9 & 360 & 34.4 & 360 & 30.4 & 360 \\
\hline Chromium III (as Cr) & 1 & 72.1 & 360 & 77.8 & 360 & 68.7 & 360 \\
\hline Chromium oxide & 1 & 72.1 & 360 & 77.8 & 360 & 68.7 & 360 \\
\hline Clay & 50 & 26.9 & 360 & 29.0 & 360 & 25.6 & 360 \\
\hline Clay (kaolin) & 20 & 129.1 & 360 & 139.3 & 360 & 123.0 & 360 \\
\hline Clay 68911-87-5 & 100 & 6.6 & 360 & 7.1 & 360 & 6.3 & 360 \\
\hline Cyclic amine epoxy polymer & 50 & 30.8 & 360 & 33.2 & 360 & 29.3 & 360 \\
\hline Cyclohexanone & 480 & 6.2 & 360 & 6.4 & 360 & 6.0 & 360 \\
\hline Diacetone alcohol & 960 & 2.2 & 231 & 2.2 & 288 & 2.1 & 108 \\
\hline Diaminocyclohexane & 470 & 2.9 & 340 & 3.1 & 360 & 2.74 & 237 \\
\hline Dibasic esters & 100 & 8.1 & 360 & 8.3 & 360 & 7.9 & 360 \\
\hline Diethylenetriamine & 40 & 19.4 & 360 & 20.1 & 360 & 19.1 & 360 \\
\hline
\end{tabular}




\section{Continued}

\begin{tabular}{|c|c|c|c|c|c|c|c|}
\hline Diisodecyl phthalate & 50 & 14.0 & 360 & 15.1 & 360 & 13.3 & 360 \\
\hline Diisodecyl phyhalate & 50 & 4.7 & 360 & 5.1 & 360 & 4.5 & 360 \\
\hline $\begin{array}{l}\text { Diphenylmethane diisocyanate } \\
\text { polymer }\end{array}$ & 3 & 463.4 & 360 & 500.2 & 360 & 441.6 & 360 \\
\hline Epoxy resin & 50 & 72.5 & 360 & 78.3 & 360 & 69.1 & 360 \\
\hline Epoxy resin 25036-25-3 & 50 & 67.4 & 360 & 72.7 & 360 & 64.2 & 360 \\
\hline Ethyl 3-ethoxypropionate & 400 & 3.3 & 360 & 3.6 & 360 & 3.2 & 290 \\
\hline Ethyl silicate & 850 & 1.2 & 21 & 1.2 & 89 & 1.2 & 36 \\
\hline $\begin{array}{l}\text { Ethyl silicate polymer } \\
\text { (as ethyl silicate) }\end{array}$ & 50 & 25.3 & 360 & 27.3 & 360 & 24.1 & 360 \\
\hline Ethylbenzene & 2000 & 1.2 & 61 & 1.3 & 108 & 1.2 & 36 \\
\hline Hansa yellow & 50 & 12.0 & 360 & 13.0 & 360 & 11.5 & 360 \\
\hline Heptane & 3500 & 1.4 & 16 & 1.56 & 164 & 1.37 & 74 \\
\hline Hexamethylene diisocyanate & 4 & 355 & 360 & 383.2 & 360 & 338.3 & 360 \\
\hline High flash naphtha & 1250 & 1.1 & 5 & 1.23 & 60 & 1.08 & 36 \\
\hline Hydrated iron oxide & 50 & 207.7 & 360 & 224.2 & 360 & 197.9 & 360 \\
\hline Hydrotreated light naphha & 3500 & 1.2 & 5 & 1.26 & 72 & 1.11 & 39 \\
\hline Iron oxide & 50 & 17.6 & 360 & 19.0 & 360 & 16.8 & 360 \\
\hline Iron oxide (red) (as fe fume) & 50 & 2.48 & 287 & 2.67 & 360 & 2.36 & 182 \\
\hline Iron phosphide & 50 & 40.7 & 360 & 43.9 & 360 & 38.8 & 360 \\
\hline Isobutanol & 1520 & 4.2 & 360 & 4.35 & 360 & 4.1 & 360 \\
\hline Isophorone diamine & 100 & 6.7 & 360 & 7.3 & 360 & 6.4 & 360 \\
\hline Lead & 1.5 & 15.4 & 360 & 16.6 & 360 & 14.7 & 360 \\
\hline Light aliphatic solvent naphtha & 3500 & 1.3 & 7 & 1.4 & 126 & 1.25 & 72 \\
\hline Light hydrotreated distallate & 1000 & 5.0 & 360 & 5.4 & 360 & 4.80 & 360 \\
\hline Medium aromatic hydrocarbons & 2560 & 2.2 & 244 & 2.3 & 308 & 2.2 & 108 \\
\hline MEKP & 15 & 14.8 & 360 & 16.0 & 360 & 14.1 & 360 \\
\hline Methyl ethyl ketone & 3900 & 2.4 & 266 & 2.5 & 360 & 2.3 & 109 \\
\hline Methyl isoamyl ketone & 60 & 20.5 & 360 & 21.2 & 360 & 20.1 & 360 \\
\hline Methyl isobutyl ketone & 2050 & 3.2 & 360 & 3.3 & 360 & 3.1 & 360 \\
\hline Methyl n-amyl ketone & 32 & 158.4 & 360 & 165.0 & 360 & 154.6 & 360 \\
\hline Methyl silicate & 60 & 1.1 & 2 & 1.2 & 45 & 1.04 & 35 \\
\hline Mica & 30 & 47.2 & 360 & 50.9 & 360 & 44.9 & 360 \\
\hline Modified aliphatic polyamine & 420 & 1.4 & 10 & 1.5 & 142 & 1.3 & 74 \\
\hline Naphthalene & 440 & 1.2 & 12 & 1.2 & 81 & 1.1 & 36 \\
\hline Nonyl phenol & 400 & 1.8 & 90 & 2.0 & 323 & 1.8 & 110 \\
\hline Nonylphenol & 400 & 2.3 & 244 & 2.5 & 358 & 2.2 & 181 \\
\hline Odorless petroleum naphtha & 3500 & 1.2 & 5 & 1.3 & 79 & 1.13 & 39 \\
\hline Organic yellow pigment & 50 & 12.0 & 360 & 13.0 & 360 & 11.5 & 360 \\
\hline
\end{tabular}


Continued

\begin{tabular}{|c|c|c|c|c|c|c|c|}
\hline Organophilic clay & 50 & 28.8 & 360 & 31.1 & 360 & 27.5 & 360 \\
\hline Paraffin waxes, hydrocarbon waxes & 20 & 78.8 & 360 & 85.1 & 360 & 75.1 & 360 \\
\hline Pentyl propionate & 230 & 6.5 & 360 & 7.0 & 360 & 6.1 & 360 \\
\hline Phenol & 150 & 3.0 & 348 & 3.2 & 360 & 2.83 & 253 \\
\hline Phenol novalac & 50 & 99.1 & 360 & 107.0 & 360 & 94.5 & 360 \\
\hline Phenolic polymer & 30 & 32.4 & 360 & 35.0 & 360 & 30.9 & 360 \\
\hline Polyamide & 50 & 37.6 & 360 & 40.6 & 360 & 35.9 & 360 \\
\hline Polyamide resin & 50 & 37.7 & 360 & 40.7 & 360 & 36.0 & 360 \\
\hline Polyamine & 180 & 9.9 & 360 & 10.7 & 360 & 9.5 & 360 \\
\hline Polyamine adduct & 50 & 7.9 & 360 & 8.6 & 360 & 7.5 & 360 \\
\hline Polyester resin & 50 & 52.0 & 360 & 56.2 & 360 & 49.6 & 360 \\
\hline Polysilicate & 10 & 23.1 & 360 & 25.0 & 360 & 22.0 & 360 \\
\hline Polystyrene & 50 & 2.2 & 191 & 2.3 & 356 & 2.1 & 146 \\
\hline Potassium hydroxide & 20 & 23.1 & 360 & 25.3 & 360 & 22.4 & 360 \\
\hline Potassium silicate & 50 & 102.6 & 360 & 110.8 & 360 & 97.8 & 360 \\
\hline $\begin{array}{l}\text { Propylene Glycol Methyl } \\
\text { Ether Acetate }\end{array}$ & 660 & 5.9 & 360 & 6.1 & 360 & 5.7 & 360 \\
\hline Propylene glycol mono methyl ether & 3700 & 1.2 & 16 & 1.2 & 84 & 1.16 & 36 \\
\hline p-Toluenesulfonyl isocyanate & 1 & 72.1 & 360 & 77.8 & 100 & 68.7 & 360 \\
\hline Quartz & 10 & 762.9 & 360 & 823.5 & 0 & 727.1 & 360 \\
\hline $\begin{array}{l}\text { Quaternary ammonium compounds, } \\
\text { benzyl-C12-16-alky }\end{array}$ & 100 & 1.7 & 60 & 1.9 & 273 & 1.65 & 110 \\
\hline Rheology additive & 50 & 6.8 & 360 & 7.3 & 360 & 6.4 & 360 \\
\hline Strontium chromate & 0.1 & 13.6 & 360 & 14.7 & 360 & 13.0 & 360 \\
\hline Talc & 20 & 252.9 & 360 & 273 & 360 & 241 & 360 \\
\hline Tetraethylenepentamine & 400 & 1.3 & 7 & 1.4 & 126 & 1.25 & 73 \\
\hline Titanate & 10 & 1.1 & 2 & 1.2 & 45 & 1.04 & 35 \\
\hline Titanium dioxide & 50 & 46 & 360 & 50 & 360 & 43.8 & 360 \\
\hline Toluene & 640 & 6.0 & 360 & 6.1 & 360 & 5.8 & 360 \\
\hline Tremolite (non-asbestiform) & 20 & 88.3 & 360 & 95.4 & 360 & 84.2 & 360 \\
\hline Triethylene tetramine & 240 & 1.3 & 7 & 1.4 & 103 & 1.2 & 51 \\
\hline Trimethyl benzene & 1250 & 1.1 & 3 & 1.14 & 61 & 1.08 & 36 \\
\hline Trimethyl borate & 13 & 13.0 & 360 & 13.4 & 360 & 12.7 & 360 \\
\hline Xylene & 350 & 30.1 & 360 & 30.7 & 360 & 29.7 & 360 \\
\hline Zinc chloride & 10 & 1.1 & 2 & 1.2 & 45 & 1.04 & 35 \\
\hline Zinc dust & 50 & 250.0 & 360 & 269.8 & 360 & 238.2 & 360 \\
\hline Zinc oxide & 50 & 25.1 & 360 & 27.1 & 360 & 23.9 & 360 \\
\hline Zinc phosphate & 50 & 19.5 & 360 & 21.0 & 360 & 18.5 & 360 \\
\hline
\end{tabular}


Volatile Organic Compound Emissions from Surface Coating Facilities: Characterization of Facilities,

Estimation of Emission Rates, and Dispersion Modeling of Off-Site Impacts

Table 8. Maximum SUM values for good practice stack + fugitives.

\begin{tabular}{|c|c|c|c|c|c|}
\hline \multirow[b]{2}{*}{ Compound } & \multirow{2}{*}{$\begin{array}{l}\text { Short-Term } \\
\text { ESL, } \mathrm{mg} / \mathrm{m}^{3}\end{array}$} & \multicolumn{2}{|c|}{ Rural 24-hour operation } & \multicolumn{2}{|c|}{ Urban 24-hour operation } \\
\hline & & $\begin{array}{c}\text { Max. Sum of } \\
(\mathrm{E} / \mathrm{ESL})^{*} \mathrm{C}, \mathrm{lb} / \mathrm{hr}\end{array}$ & $\begin{array}{l}\text { Number of Sum } \\
\text { Values }>1\end{array}$ & $\begin{array}{c}\text { Max. Sum of } \\
(\mathrm{E} / \mathrm{ESL})^{*} \mathrm{C}, \mathrm{lb} / \mathrm{hr}\end{array}$ & $\begin{array}{l}\text { Number of Sum } \\
\text { Values }>1\end{array}$ \\
\hline 1,3,5-Trimethylbenzene & 1250 & 1.02 & 69 & 1.03 & 36 \\
\hline 2,4-pentanedione & 40 & 1.21 & 6 & 1.95 & 252 \\
\hline 2-Butoxyethyl acetate & 310 & 2.9 & 360 & 2.96 & 252 \\
\hline 4,4'-diphenylomethane diisocyanate & 0.5 & 658.4 & 360 & 666.1 & 360 \\
\hline Acrylic polymer A & 50 & 3.1 & 324 & 5.0 & 360 \\
\hline Alkyl phthalate & 50 & 4.2 & 324 & 6.8 & 360 \\
\hline Aluminum oxide & 50 & 1.4 & 16 & 2.2 & 288 \\
\hline Aluminum silicate & 50 & 6.14 & 324 & 9.9 & 360 \\
\hline Anthophyllite (non-asbestiform) & 20 & 0.8 & 0 & 1.3 & 3 \\
\hline Antigorite & 20 & 4.5 & 324 & 7.2 & 360 \\
\hline Barium chromate & 0.1 & 3.4 & 324 & 5.5 & 360 \\
\hline Barium metaborate hydrate & 50 & 2.4 & 288 & 3.8 & 324 \\
\hline Barium sulfate & 50 & 21.6 & 324 & 34.9 & 360 \\
\hline Benzyl alcohol & 500 & 1.8 & 252 & 1.8 & 73 \\
\hline Butoxyethoxyethanol & 1060 & 0.7 & 0 & 1.16 & 3 \\
\hline Butyl acetate & 36 & 142.8 & 360 & 144 & 360 \\
\hline Butyl alcohol & 610 & 3.9 & 360 & 3.94 & 148 \\
\hline $\begin{array}{l}\text { C18 unsaturated dimers, } \\
\text { polymer w/BPA and ech }\end{array}$ & 50 & 26.5 & 324 & 42.8 & 360 \\
\hline Calcium carbonate & 50 & 7.4 & 324 & 11.9 & 360 \\
\hline Calcium magnesium carbonate & 50 & 2.5 & 288 & 4.1 & 360 \\
\hline Ceramic metals and wares & 50 & 8.2 & 324 & 13.2 & 360 \\
\hline Chromium III (as Cr) & 1 & 18.4 & 324 & 29.8 & 360 \\
\hline Chromium oxide & 1 & 18.4 & 324 & 29.8 & 360 \\
\hline Clay & 50 & 6.9 & 324 & 11.1 & 360 \\
\hline Clay (kaolin) & 20 & 33.0 & 324 & 53.3 & 360 \\
\hline Clay 68911-87-5 & 100 & 1.7 & 215 & 2.7 & 324 \\
\hline Cyclic amine epoxy polymer & 50 & 7.9 & 324 & 12.7 & 360 \\
\hline Cyclohexanone & 480 & 3.7 & 360 & 3.8 & 216 \\
\hline Diacetone alcohol & 960 & 1.3 & 145 & 1.3 & 37 \\
\hline Diaminocyclohexane & 470 & 0.74 & 0 & 1.2 & 3 \\
\hline Dibasic esters & 100 & 4.9 & 360 & 4.9 & 288 \\
\hline
\end{tabular}




\section{Continued}

\begin{tabular}{|c|c|c|c|c|c|}
\hline Diethylenetriamine & 40 & 11.8 & 360 & 11.9 & 360 \\
\hline Diisodecyl phthalate & 50 & 3.6 & 324 & 5.8 & 360 \\
\hline Diisodecyl phyhalate & 50 & 1.2 & 6 & 1.96 & 252 \\
\hline Diphenylmethane diisocyanate polymer & 3 & 118.5 & 357 & 191.4 & 360 \\
\hline Epoxy resin & 50 & 18.5 & 324 & 30.0 & 360 \\
\hline Epoxy resin 25036-25-3 & 50 & 17.2 & 324 & 27.8 & 360 \\
\hline Ethyl 3-ethoxypropionate & 400 & 0.85 & 0 & 1.4 & 4 \\
\hline Ethyl silicate & 850 & 0.7 & 0 & 0.73 & 0 \\
\hline Ethyl silicate polymer (as ethyl silicate) & 50 & 6.5 & 324 & 10.5 & 360 \\
\hline Ethylbenzene & 2000 & 0.84 & 0 & 0.84 & 0 \\
\hline Hansa yellow & 50 & 3.1 & 324 & 5.0 & 360 \\
\hline Heptane & 3500 & 0.37 & 0 & 0.6 & 0 \\
\hline Hexamethylene diisocyanate & 4 & 90.8 & 324 & 146.7 & 360 \\
\hline High flash naphtha & 1250 & 0.29 & 0 & 0.47 & 0 \\
\hline Hydrated iron oxide & 50 & 53.1 & 324 & 85.8 & 260 \\
\hline Hydrotreated light naphha & 3500 & 0.3 & 0 & 0.5 & 0 \\
\hline Iron oxide & 50 & 4.5 & 324 & 7.3 & 360 \\
\hline Iron oxide (red) (as fe fume) & 50 & 0.63 & 0 & 1.02 & 1 \\
\hline Iron phosphide & 50 & 10.4 & 324 & 16.8 & 360 \\
\hline Isobutanol & 1520 & 2.55 & 360 & 2.6 & 112 \\
\hline Isophorone diamine & 100 & 1.72 & 231 & 2.8 & 324 \\
\hline Lead & 1.5 & 3.9 & 324 & 6.4 & 360 \\
\hline Light aliphatic solvent naphtha & 3500 & 0.34 & 0 & 0.54 & 0 \\
\hline Light hydrotreated distallate & 1000 & 1.3 & 10 & 2.10 & 252 \\
\hline Medium aromatic hydrocarbons & 2560 & 1.34 & 145 & 1.35 & 37 \\
\hline MEKP & 15 & 3.8 & 324 & 6.1 & 360 \\
\hline Methyl ethyl ketone & 3900 & 1.2 & 109 & 1.2 & 37 \\
\hline Methyl isoamyl ketone & 60 & 12.4 & 360 & 12.5 & 360 \\
\hline Methyl isobutyl ketone & 2050 & 1.83 & 254 & 1.85 & 74 \\
\hline Methyl n-amyl ketone & 32 & 83.0 & 360 & 83.9 & 360 \\
\hline Methyl silicate & 60 & 0.28 & 0 & 0.45 & 0 \\
\hline Mica & 30 & 12.1 & 324 & 19.5 & 360 \\
\hline Modified aliphatic polyamine & 420 & 0.36 & 0 & 0.6 & 0 \\
\hline Naphthalene & 440 & 0.7 & 0 & 0.71 & 0 \\
\hline Nonyl phenol & 400 & 0.5 & 0 & 0.76 & 0 \\
\hline Nonylphenol & 400 & 0.6 & 0 & 0.96 & 0 \\
\hline Odorless petroleum naphtha & 3500 & 0.3 & 0 & 0.49 & 0 \\
\hline
\end{tabular}




\section{Continued}

\begin{tabular}{|c|c|c|c|c|c|}
\hline Organic yellow pigment & 50 & 3.1 & 324 & 5.0 & 360 \\
\hline Organophilic clay & 50 & 7.4 & 324 & 11.9 & 360 \\
\hline Paraffin waxes, hydrocarbon waxes & 20 & 20.2 & 324 & 32.6 & 360 \\
\hline Pentyl propionate & 230 & 1.7 & 188 & 2.7 & 324 \\
\hline Phenol & 150 & 0.76 & 0 & 1.2 & 3 \\
\hline Phenol novalac & 50 & 25.3 & 324 & 40.9 & 360 \\
\hline Phenolic polymer & 30 & 8.3 & 324 & 13.4 & 360 \\
\hline Polyamide & 50 & 9.6 & 324 & 15.5 & 360 \\
\hline Polyamide resin & 50 & 9.7 & 324 & 15.6 & 360 \\
\hline Polyamine & 180 & 2.5 & 288 & 4.1 & 360 \\
\hline Polyamine adduct & 50 & 2.0 & 288 & 3.3 & 324 \\
\hline Polyester resin & 50 & 13.3 & 324 & 21.5 & 360 \\
\hline Polysilicate & 10 & 5.9 & 324 & 9.6 & 360 \\
\hline Polystyrene & 50 & 0.55 & 0 & 0.9 & 0 \\
\hline Potassium hydroxide & 20 & 6.0 & 324 & 9.7 & 360 \\
\hline Potassium silicate & 50 & 26.2 & 324 & 42.4 & 360 \\
\hline Propylene glycol methyl ether acetate & 660 & 3.0 & 360 & 3.1 & 216 \\
\hline Propylene glycol mono methyl ether & 3700 & 0.7 & 0 & 0.7 & 0 \\
\hline p-Toluenesulfonyl isocyanate & 1 & 18.4 & 324 & 29.8 & 360 \\
\hline Quartz & 10 & 195.1 & 360 & 315 & 360 \\
\hline $\begin{array}{l}\text { Quaternary ammonium compounds, } \\
\text { benzyl-C12-16-alky }\end{array}$ & 100 & 0.44 & 0 & 0.7 & 0 \\
\hline Rheology additive & 50 & 1.7 & 249 & 2.8 & 324 \\
\hline Strontium chromate & 0.1 & 3.5 & 324 & 5.6 & 360 \\
\hline Talc & 20 & 64.7 & 324 & 104.5 & 360 \\
\hline Tetraethylenepentamine & 400 & 0.34 & 0 & 0.5 & 0 \\
\hline Titanate & 10 & 0.28 & 0 & 0.45 & 0 \\
\hline Titanium dioxide & 50 & 11.8 & 324 & 19 & 360 \\
\hline Toluene & 640 & 3.8 & 360 & 3.8 & 183 \\
\hline Tremolite (non-asbestiform) & 20 & 22.6 & 324 & 36.5 & 360 \\
\hline Triethylene tetramine & 240 & 0.32 & 0 & 0.5 & 0 \\
\hline Trimethyl benzene & 1250 & 0.67 & 0 & 0.67 & 0 \\
\hline Trimethyl borate & 13 & 7.9 & 360 & 7.9 & 360 \\
\hline Xylene & 350 & 22.9 & 360 & 23 & 360 \\
\hline Zinc chloride & 10 & 0.28 & 0 & 0.45 & 0 \\
\hline Zinc dust & 50 & 63.9 & 324 & 103.3 & 360 \\
\hline Zinc oxide & 50 & 6.4 & 324 & 10.4 & 360 \\
\hline Zinc phosphate & 50 & 5.0 & 324 & 8 & 369 \\
\hline
\end{tabular}


were included in the SUM, to correspond to the 1-hour averaging time of the short-term ESLs. Although TCEQ also provides long-term (annual) effect screening levels, short-term ESLs generally result in more stringent permit limits than long-term ESLs. Thus, only short-term ESLs were considered. Concentrations were calculated for both urban and rural dispersion parameters, because depending on the receptor location, either could be higher for the stack configurations.

SUMS were calculated for all 360 receptor locations. If SUM $<1$ is for a given species for all receptor locations, that pollutant would not warrant in-depth health review. For those pollutants where SUM $>1$, further analysis may be required through pollutant specific modeling analyses.

Table 7 lists maximum SUM values for the 108 (out of 181) pollutants with SUM $>1$ for the worst-case stack + fugitives for the 24-hour operation scenario for rural and urban dispersion parameters, as well as the 8-hour operation scenario for rural dispersion parameters is also presented for comparison. Table 8 lists the maximum SUM values for the good-practice stack + fugitives. As seen in Tables $\mathbf{7}$ and $\mathbf{8}$, the worst-case stack + fugitives 24-hour operation scenario with rural dispersion parameters gave the highest concentrations. This was anticipated because worst-case stack gave higher concentrations than the good-practice stack, the 24-hour operation scenario gave higher concentrations than the 8-hour operation scenario for the worst-case stack, and the rural dispersion parameters gave higher fugitive concentrations.

The pollutants listed in Tables $\mathbf{7}$ and $\mathbf{8}$ warrant a more in-depth health impacts evaluation.

\section{Summary}

A database was developed using 286 TCEQ permit files authorizing surface coating facilities in Texas during 2006 and 2007. The database includes information important for estimating emission rates, and for using as dispersion model inputs.

Hourly and annual emissions of volatile organic compounds (VOCs), particulate matter (PM), and exempt solvents (ES) were calculated for each permitted entity/ company in the database, according to equations given by TCEQ. Dispersion modeling was then conducted for 3 facility configurations (worst-case stack height, good practice stack height, and fugitive emissions), for urban and rural dispersion parameters, for 8-hour and 24-hour operating scenarios, and for 1-hour, 24-hour, and annual averaging times, for a total of 36 scenarios. The highest modeled concentrations were for the worst-case stack height, rural dispersion parameters, 24-hour operation scenario, and 1-hour averaging time. 108 specific chemi- cal species, which are components of surface coatings, were identified as candidates for further health impacts review.

\section{Acknowledgements}

We would like to acknowledge the Texas Commission on Environmental Quality for providing funding for this project. The paper does not, however, necessarily represent the opinions or positions of TCEQ.

\section{REFERENCES}

[1] US Environmental Protection Agency (EPA), "Vol. I, Chapter 4, Evaporation Loss Sources, Section 4.2.2.1, General Industrial Surface Coating," In: US Environmental Protection Agency (EPA) AP-42, 5th Edition, 1981.

http://www.epa.gov/ttn/chief/ap42/ch04/final/c4s02_2a.p df

[2] A. Kumar and T. Shenoy, "Surface Coatings," In: W. T. Davis, Ed., Air Pollution Engineering Manual, John Wiley \& Sons, Inc., New York, 2000, pp. 321-332.

[3] R. Mukund, T. J. Kelly and C. W. Spicer, "Source Attribution of Ambient Air Toxic and Other VOCs in Columbus, Ohio,” Atmospheric Environment, Vol. 30, No. 20, 1996, pp. 3457-3470. doi:10.1016/1352-2310(95)00487-4

[4] J. H. Lawrimore and V. P. Aneja, “Chemical Mass Balance Analyses of Nonmethane Hydrocarbon Emissions in North Carolina," Chemosphere, Vol. 35, No. 11, 1997, pp. 2751-2765. doi:10.1016/S0045-6535(97)00321-4

[5] M. Placet, C. O. Mann, R. O. Golbert and M. J. Niefer, "Emissions of Ozone Precursors from Stationary Source: A Critical Review,” Atmospheric Environment, Vol. 34, No. 12-14, 2000, pp. 2183-2204. doi:10.1016/S1352-2310(99)00464-1

[6] S. Pierucci, R. Del Rosso, D. Bombardi, A. Concu and G. Lugli, "An Innovative Sustainable Process for VOCs Recovery from Spray Paint Booths,” Energy, Vol. 30, No. 8, 2005, pp. 1377-1386. doi:10.1016/j.energy.2004.02.017

[7] US Environmental Protection Agency (EPA), "Vol. I, Chapter 4, Evaporation Loss Sources, Section 4.2.1, Nonindustrial Surface Coating," In: US Environmental Protection Agency (EPA) AP-42, 5th Edition, 1991. http://www.epa.gov/ttn/chief/ap42/ch04/final/c4s02_1.pdf

[8] Y. J. Choi, R. V. Calabrese, S. H. Ehrman, R. R. Dickerson and J. W. Stehr, "A Combined Approach for the Evaluation of a Volatile Organic Compound Emissions Inventory," Journal of the Air \& Waste Management Association, Vol. 56, No. 2, 2006, pp. 169-178. doi:10.1080/10473289.2006.10464446

[9] K. Mannschreck, D. Klemp, D. Kley, R. Friedrich, J. Huhlwein, B. Wickert, P. Matuska, M. Habram and F. Slemr, "Evaluation of an Emission Inventory by Comparisons of Modeled and Measured Emission Ratios of Individual HCS, CO and $\mathrm{NO}_{\mathrm{x}}$, , Atmospheric Environment, Vol. 36, Suppl. 1, 2002, pp. 581-594. 


\section{doi:10.1016/S1352-2310(02)00211-X}

[10] J. G. Watson, J. C. Chow and E. M. Fujita, "Review of Volatile Organic Compound Source Apportionment by Chemical Mass Balance,” Atmospheric Environment, Vol. 36, No. 9, 2001, pp. 1567-1584. doi:10.1016/S1352-2310(00)00461-1

[11] A. Srivastava and D. Majumdar, "Emission Inventory of Evaporative Emissions of VOCs in Four Metro Cities in India,” Environmental Monitoring Assessment, Vol. 160, No. 1-4, 2010, pp. 315-322. doi:10.1007/s10661-008-0697-4

[12] P. M. Randall, "Pollution Prevention Methods in the Surface Coating Industry," Journal of Hazardous Materials, Vol. 29, No. 2, 1992, pp. 275-295. doi:10.1016/0304-3894(92)85073-A

[13] C. M. Smith and W. E. Brown, "Elimination of VOC Emissions from Surface Coating Operations,” Journal of the Air \& Waste Management Association, Vol. 43, No. 7, 1993, pp. 1015-1019.

[14] C. H. Darvin, D. Proffitt and J. Ayer, "Paint Spray Booth Design Using Recirculation/Partitioning Ventilation,” Environmental Progress, Vol. 17, No. 3, 1998, pp. 199-202. doi:10.1002/ep.670170320

[15] M. J. McFarland, G. R. Palmer, S. Peters, A. C. Olivas and T. M. Nelson, "Maintaining High-Volume, LowPressure Surface-Coating Regulatory Compliance Using the U.S. Environmental Protection Agency’s Data Quality
Objectives Process," Journal of the Air \& Waste Management Association, Vol. 55, No. 3, 2005, pp. 365-372. doi:10.1080/10473289.2005.10465924

[16] M. J. McFarland, T. M. Nelson and G. R. Palmer, "Development of a Hazardous Air Pollutants Monitoring Program Using the Data Quality Objectives Process,” Journal of the Air \& Waste Management Association, Vol. 54, No. 5, 2004, pp. 614-622. doi:10.1080/10473289.2004.10470932

[17] F. J. Álvarez-Hornos, C. Lafita, V. Martínez-Soria, J. M. Penya-Roja, M. C. Pérez and C. Gabaldón, "Evaluation of a Pilot-Scale Biotrickling Filter as a VOC Control Technology for the Plastic Coating Sector,” Biochemical Engineering Journal, Vol. 58-59, 2011, pp. 154-161.

[18] R. A. Wadden, P. A. Scheff, J. E. Franke, L. M. Conroy, M. Javor, C. B. Keil and S. A. Milz, "VOC Emission Rates and Emission Factors for a Sheetfed Offset Printing Shop," American Industrial Hygiene Association Journal, Vol. 56, No. 4, 1995, pp. 368-376. doi:10.1080/15428119591016999

[19] J. E. McCarthy and D. W. Senser, "Numerical Model of Paint Transfer and Deposition in Electrostatic Air Sprays," Atomization and Sprays, Vol. 16, No. 2, 2006, pp. 195222. doi:10.1615/AtomizSpr.v16.i2.40

[20] M. Coldiron and E. Mack, "Painting Basics and Emission Calculations for TCEQ Air Quality Permit Applications," 2006. 